\title{
2. INTRODUCTION AND EXPLANATORY NOTES, LEG 48, IPOD PHASE OF THE DEEP SEA DRILLING PROJECT
}

\author{
L. Montadert, Institut Français du Pétrole, 92500 Rueil Malmaison, France, \\ D.G. Roberts, Institute of Oceanographic Sciences, Wormley, Godalming GU8 5UB, Surrey, England \\ and \\ R.W. Thompson, California State University, Arcata, California
}

\section{BACKGROUND AND PLANNING OF LEG 48}

Unlike many cruises of the Deep Sea Drilling Project, Leg 48 was scientifically planned to drill a number of sites to systematically address the problems of passive margin evolution. These problems have been discussed in the preceding chapter. Sites drilled during Leg 48 (Figure 1) were selected on the continental margin of the Bay of Biscay and on the Rockall Plateau. Both these margins are characterized by reduced Tertiary progradation thus enabling safe penetration of the synrift and prerift sediments at shallow depths. The two margins also offered a contrast in both age and structure. The margin of the Bay of Biscay apparently formed by rifting at about $130 \mathrm{~m} . \mathrm{y}$. and is structured into a series of rifted blocks and half-grabens overlain by a thin Cretaceous and Tertiary cover. The southwest Rockall Plateau which was rifted at about 60 m.y. B.P. does not show a prominent horst and graben structure but, instead, consists of a thick deltaic (?) sequence closely similar to that observed beneath the outer Vøring Plateau off Norway. In order to ensure maximum flexibility in the drilling program, many alternate sites were proposed and accepted by the Safety Panel. The intention was to have the facility to modify the program according to the first drilling results without reference to DSDP. This proved fortunate because the ship's drilling capability was considerably reduced following the loss of the drill string at Hole 400A. Although Site 401 was drilled with the ready concurrence of the Chief Scientist of DSDP, Hole 402A was chosen from the data and site proposals onboard. This flexibility again proved useful in drilling Site 404 on the Rockall Plateau.

The principal objectives of Leg 48 are given in the preceding chapter and the individual objectives of each site in each site chapter.

\section{LEG 48 OPERATIONAL SUMMARY}

Leg 48 of the International Phase of Ocean Drilling of the Deep Sea Drilling Project began on 12 May 1976 and ended 61.86 days later in Aberdeen, Scotland, on 13 July 1976. During this leg, Glomar Challenger traveled 1935.4 nautical miles and drilled 10 holes at eight sites. Water depths ranged from 4414 meters to 2317 meters and averaged 3099 meters. Hole depths ranged from 72.5 meters to 831.5 meters and averaged 399.2 meters. A total of 2995.5 meters was cored and 1230.22 meters of core were recovered representing some 41.06 per cent (Table 1).

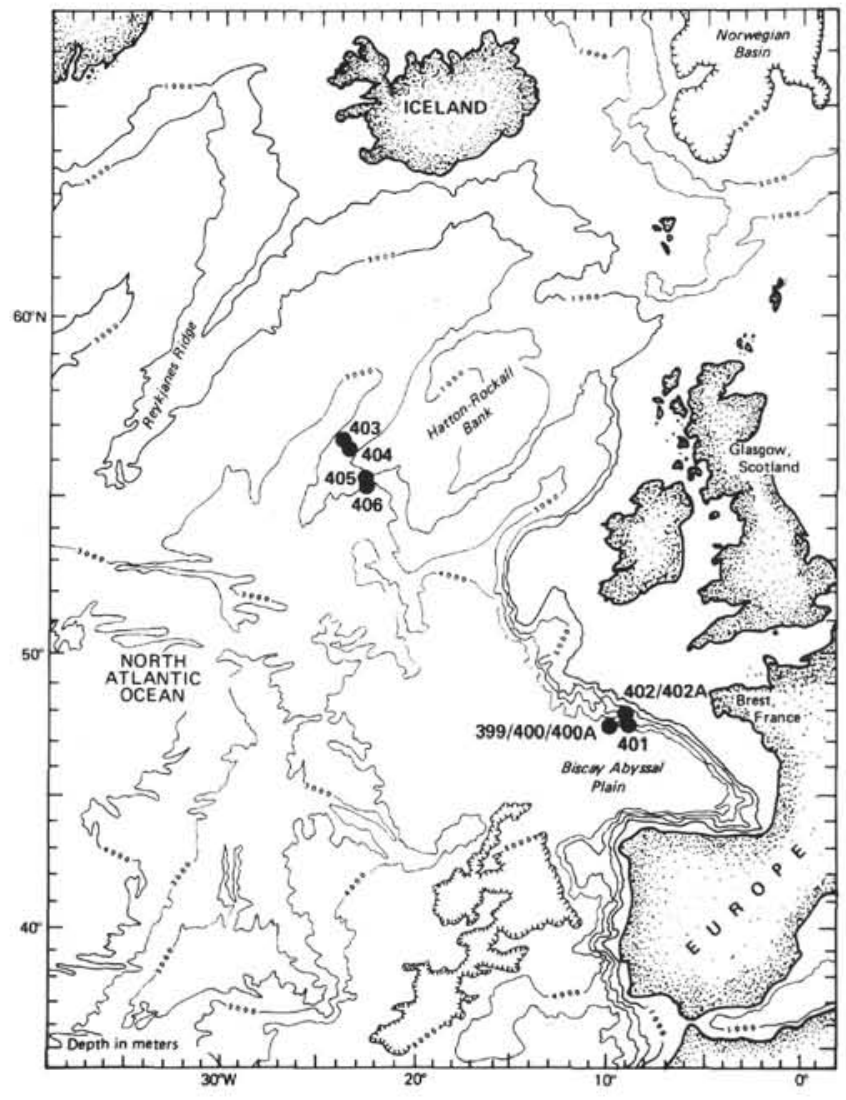

Figure 1. Location of Sites 399 through 406 drilled on DSDP Leg 48.

Time distribution for the leg was 9.65 days in port, 11.41 days cruising, and 40.8 days on site. The on-site time consisted of 8.6 days tripping, 0.09 days drilling, 20.9 days coring, 0.6 days positioning the ship, 0.57 days for mechanical downtime, 0.54 days in re-entry operations, 1.8 days waiting on weather, and 7.7 days in miscellaneous activities such as picking up a new drill string and running downhole logs.

The most serious problem encountered during the leg was the loss of 5056 meters of drill pipe plus the bottom-hole assembly when the pin end of the pup joint attached to the Bowen-sub broke shortly after re-entering Hole 400A. The remaining drill string length onboard effectively restricted subsequent drilling operations to depths of less than 3000 
TABLE 1

Coring Summary, Leg 48

\begin{tabular}{|c|c|c|c|c|c|c|c|c|c|}
\hline Hole & Dates & Latitude & Longitude & $\begin{array}{c}\text { Water } \\
\text { Depth }(\mathrm{m})\end{array}$ & Penetration & $\begin{array}{l}\text { No. of } \\
\text { Cores }\end{array}$ & $\begin{array}{r}\text { Meters } \\
\text { Cored }\end{array}$ & $\begin{array}{c}\text { Meters } \\
\text { Recovered }\end{array}$ & Recovery (\%) \\
\hline 399 & 23 to 24 May & $47^{\circ} 23.4^{\prime} \mathrm{N}$ & $09^{\circ} 13.3^{\prime} \mathrm{W}$ & 4399 & 72.5 & 2 & 17.5 & 11.77 & - \\
\hline 400$\}$ & 24 May to & $47^{\circ} 22.90^{\prime} \mathrm{N}$ & $09^{\circ} 11.90^{\prime} \mathrm{W}$ & 4399 & - & 1 & - & - & - \\
\hline $400 A^{\zeta}$ & 6 June & $47^{\circ} 22.90^{\prime} \mathrm{N}$ & $09^{\circ} 11.90^{\prime} \mathrm{W}$ & 4399 & 777.5 & 74 & 729.5 & 350.86 & 48 \\
\hline 401 & $\begin{array}{l}6 \text { June to } \\
10 \text { June }\end{array}$ & $47^{\circ} 25.65^{\prime} \mathrm{N}$ & $08^{\circ} 48.62^{\prime} \mathrm{W}$ & 2495 & 341.0 & 28 & 265.0 & 103.22 & 38.7 \\
\hline 402$\}$ & 10 June to & $47^{\circ} 52.48^{\prime} \mathrm{N}$ & $08^{\circ} 50.44^{\prime} \mathrm{W}$ & 2339.5 & 137.0 & 5 & 42.0 & 12.19 & 29.0 \\
\hline $402 A^{3}$ & 16 June & & & & 469.5 & 35 & 332.5 & 167.5 & 50.0 \\
\hline 403 & $\begin{array}{l}20 \text { June to } \\
24 \text { June }\end{array}$ & $56^{\circ} 08.31^{\prime} \mathrm{N}$ & $23^{\circ} 17.64^{\prime} W$ & 2301 & 489.0 & 52 & 489.0 & 160.83 & 32.9 \\
\hline 404 & $\begin{array}{l}25 \text { June to } \\
29 \text { June }\end{array}$ & $56^{\circ} 03.13^{\prime} \mathrm{N}$ & $23^{\circ} 14.95^{\prime} \mathrm{W}$ & 2306 & 389.0 & 26 & 243.5 & 74.85 & 30.7 \\
\hline 405 & $\begin{array}{l}29 \text { June to } \\
4 \text { July }\end{array}$ & $55^{\circ} 20.18^{\prime} \mathrm{N}$ & $22^{\circ} 03.49^{\prime} \mathrm{W}$ & 2958 & 407.0 & 43 & 407.0 & 172.05 & 42.7 \\
\hline 406 & 4 to 9 July & $55^{\circ} 15.50^{\prime} \mathrm{N}$ & $22^{\circ} 05.41^{\prime} \mathrm{W}$ & 2907 & 8341.0 & 53 & 489.5 & 189.42 & 38.69 \\
\hline
\end{tabular}

meters, requiring a drastic revision of the Bay of Biscay drilling program.

Logging of single-bit holes was successfully carried out for the first time during Leg 48 . To achieve this, the bit was attached to a bit disconnect assembly in turn connected to the standard bottom-hole assembly. During drilling operations, this bit disconnect assembly was held in place by removable lugs also held in place by a shifting sleeve. At the logging depth, a shifting tool is lowered to move the sleeve from behind the lugs allowing them to fall in, thereby releasing the bit. This operation was successful on four of the five holes that were logged. The exception was Site 406 where the bit was released before the shifting tool was used.

Nine beacons were used during the leg and all performed well with the exception of those used at Site 399. The signal from the $16-\mathrm{Hz}$ beacon deployed initially deteriorated so much that a $13.5-\mathrm{Hz}$ beacon was dropped though this also gave a weak signal. While attempting to position on this second beacon, the signal from the first became stronger. Offsets were dialed in and the first beacon was used again. However, this signal became unusable, and the ship was moved to Holes 400/400A where another beacon was deployed.

Positioning on this leg was excellent except for the problems encountered at Site 399. The only other occasion that the ship moved off position was at Site 404 when extreme weather conditions made it impossible to hold position. At Site 401, the ship was held on location in manual and semi-automatic mode while repairs were made to the gyro compass. Accurate navigation of the ship during approaches to sites was difficult because no speed log was available. This resulted in delays of several hours while awaiting good satellite fixes.

The heave compensator was not used until Core 74 of Hole 400A had been cut. It was used again at Site 401 and was taken out for logging. It was put in the string for Site 402 and pulled out for logging. At Site 403 , it was used and locked out to assess differences in recovery and penetration rate. The heave compensator was not used for the balance of the leg because of the rapidly changing weather conditions and the need to be able to clear the mudline quickly.

Re-entry was scheduled only for Hole 400A. After drilling to 5176.5 meters, the drill string was tripped to examine the bit for the cause of the poor recovery. After changing the bit, the hole was re-entered after positioning for 1 hour and 23 minutes, although the drill string was lost shortly afterward.

Fourteen heat flow measurements were made of which 10 were run while the heave compensator was in the drill string.

The weather was generally good for much of the leg, but adverse conditions affected operations on two occasions prematurely terminating logging at Site 403 and drilling at Site 404.

\section{SUMMARY OF SCIENTIFIC RESULTS}

Detailed scientific results at each site are reported in the Site Report chapters (Chapters 3 through 7, this volume). Overall synopses have been published previously in both general and specific form (Montadert, Roberts, et al., 1976; Montadert, Roberts, et al., 1977). At the end of this volume, a series of chapters synthesize the results of the cruise in terms of the major problems and processes of passive margin evolution.

The following section offers a brief synopsis of the major scientific results at each site. The general stratigraphy of each site is summarized in Figure 2 (in back pocket) which can be found in more detail on the superlogs enclosed at the end of the volume.

\section{Principal Results}

\section{Site 399}

Site 399 was drilled as a pilot hole to determine the depth to which casing could be washed during the intended subsequent re-entry hole. Thruster malfunction and beacon signal deterioration forced a move to Site $400,0.1$ mile east-southeast before further drilling could begin. The section penetrated at Site 399 consisted mainly of olive-gray marly calcareous ooze of Pleistocene age.

\section{Holes 400/400A}

Site 400 was drilled at the foot of the Meriadzek Escarpment of North Biscay in 4399 meters depth. The site was located in a half-graben forming part of a succession of tilted and rotated fault blocks near the continent/ocean 
boundary. The main objectives were to define the nature of the pre-, syn-, and post-rifting environments, the regional unconformities, the paleoceanography, and the subsidence history.

Hiatuses were found between the lowermost Pliocene and the uppermost Miocene, within the lower Miocene, between the Oligocene and the middle Eocene, between the upper Paleocene and the Upper Cretaceous, and between the Campanian and the Albian. Four lithologic units and eight sub-units were recognized.

Unit 1 (0 to $413 \mathrm{~m}$ ) comprises nannofossil ooze, nannofossil chalks, and marly ooze and chalk which range in age from Holocene to early Miocene. Unit 2 (413 to 640 $\mathrm{m}$ ) ranges in age from early Miocene to late Paleocene. As a whole, this unit is less calcareous and contains a much larger component of siliceous biogenous remains especially in the middle Eocene. Unit 3 (640 to $654 \mathrm{~m}$ ) comprises calcareous and marly nannofossil chalks of late Campanian to Maestrichtian age, and is defined at its base by a $30-\mathrm{m}$.y. hiatus. Unit 4 (654 to $777.5 \mathrm{~m}$ ), of Albian to late Aptian age, comprises carbonaceous claystones interbedded with calcareous mudstones. The calcareous mudstones were deposited by turbidity currents whereas the carbonaceous claystones correspond to normal pelagic sediments deposited in a deep environment close to the CCD. The organic matter is carbonaceous material of terrestrial origin. Because no marine organic matter was found, there is no indication that anoxic conditions existed in the Bay of Biscay during the Early Cretaceous. The 30-m.y. hiatus separating the Albian-Aptian "black shales" from the Campanian-Maestrichtian nannofossil chalks is contemporaneous with the well-known global transgression and separates formations both of which were deposited in deep water.

Within the Tertiary, variations in carbonate, biogenic silica, and clay content along with the observed hiatuses apparently reflect fluctuations in CCD level, bottom current activity and surface productivity.

\section{Site 401}

Site 401 was situated on the planated edge of a tilted fault-block underlying the southern edge of the Meriadzek Terrace on the north Biscay margin. The site was continuously cored below 84.5 meters and terminated in Kimmeridgian-Portlandian shallow water carbonates at 341.0 meters.

Four lithologic units were distinguished. Unit $1(0-20 \mathrm{~m})$ of Quaternary age consists of olive-gray calcareous mud and yellowish brown calcareous ooze. Unit 2 (20 to $171.5 \mathrm{~m}$ ), of middle Oligocene (or younger) to middle Eocene age, consists of greenish gray nannofossil chalk and marly nannofossil chalk. An 18-m.y. hiatus separates the middle Eocene from the uppermost Eocene-lower Oligocene. Unit 3 (171.5 to $247.0 \mathrm{~m}$ ) is of early Eocene to Late Cretaceous age. The Eocene and uppermost Paleocene beds consist of yellowish brown to orange-brown nannofossil and marly calcareous chalks. Hiatuses are present between the lower and upper Paleocene and between the lower Paleocene and the Maestrichtian. The Maestrichtian to Campanian beds consist of laminated nannofossil and foraminiferal calcareous chalk. Unit 4 is of late Aptian to Kimmeridgian-Port- landian age and is separated by a 34-m.y. hiatus from Unit 3. Thin upper Aptian oozes comprise the upper part of the sequence and are separated by a large gap from the underlying bioclastic limestones which indicate ages from possible Neocomian at the top to late Tithonian to Berriasian. This gap corresponds to erosion during the Early Cretaceous of the crest of the tilting block. Intraclast grainstones comprising the lowest part of the unit are of Kimmeridgian to Portlandian age.

The presence of shallow water Aptian carbonates in contrast to the carbonaceous claystones and mudstones in Hole 400A shows that a substantial submarine relief $(\sim 2000 \mathrm{~m})$ existed at the end of the rifting phase. Following subaerial erosion during the Early Cretaceous at this site, the deposition of late Aptian chalks in an outer-shelf environment indicates that subsidence began in Aptian time. The Campanian-Maestrichtian chalks were deposited in 1500 meters depth and the Tertiary beds close to the present depth. Discovery of coralline debris in the KimmeridgianPortlandian section, in the Tithonian-Berriasian and in the Neocomian, suggests the existence of a large carbonate platform dissected by rifting. Less probably the deposition of these shallow water carbonates could have been restricted to bathymetric highs forming the top of tilted blocks previously created during the Late Jurassic. Abundant biogenic silica in the middle Eocene section is associated with a decrease in surface and bottom water temperatures and with a prominent unconformity marking erosion.

\section{Holes 402/402A}

Site 402 was located on the upper slope of the northern continental margin of the Bay of Biscay. The main objectives were to establish the presence or absence of shallow water Upper Cretaceous beds, and to penetrate pre-Aptian synrift sediments and the upslope equivalent of the deep water Albian-Aptian carbonaceous mudstones penetrated at Hole 400A.

Three lithological units were distinguished: Unit 1 ( 0 to $175.0 \mathrm{~m}$ ) is composed of Quaternary to middle Miocene nannofossil ooze and siliceous nannofossil chalk of late Eocene age deposited in a bathyal or upper-slope environment. The base of the unit is defined by a hiatus of at least $55 \mathrm{~m} . \mathrm{y}$. between the Albian and middle Eocene. Unit 2 ( 175 to $232 \mathrm{~m}$ ) is Albian in age and consists of extremely lithified limestones exhibiting sound velocities up to $3 \mathrm{~km} / \mathrm{s}$. The main facies include vuggy bioclastic limestones, silicified limestones with large sponge spicules, and a fine-grained micritic limestone indicating deposition in a shelf environment. Unit 3 (232.0 to $469.5 \mathrm{~m}$ ) consists of carbonaceous marly limestone, carbonaceous calcareous mudstone, and carbonaceous marly calcareous chalk of Albian and Aptian age. Two major depositional sequences recognized in these beds reflect changing environments in very shallow water depths conditioned by the balance between a large terrigenous input and subsidence of the margin following rifting.

The Albian-Aptian section may have been deposited as part of a delta complex built on the subsiding shelf. The terrigenous "black shale", sediments may have been derived by reworking of coastal plain sediments colonized 
by abundant vegetation. Reduction in the supply of terrigenous material in late Albian time may indicate inundation of the source by rising sea level. The abnormal lithification of the Albian sediments just below the hiatus is ascribed to precipitation of silica from silica-enriched interstitial water. The middle Eocene sediments are characterized by abundant silica and a deep water fauna indicative of deposition in bathyal conditions. The deep water fauna is contaminated by a displaced shelf fauna and flora containing species indicative of nearshore conditions. This floral evidence of reworking may indicate erosion of the shelf, perhaps associated with the global early-middle Eocene regression and/or tectonic deformation at that time.

\section{Site $\mathbf{4 0 3}$}

Site 403 was drilled on the southwest rifted margin of the Rockall Plateau in a sediment-filled basin that strikes parallel to, and lies $30 \mathrm{~km}$ east of, the oldest magnetic anomaly (24) recorded in the adjacent ocean crust. At the site, a thick, faulted section of deltaic aspect is unconformably overlain by a thin sequence of sediments, pelagic in their upper part and progradational below. The main objective of drilling was to determine the nature of the unconformity and the sediments beneath it, and their relation to the rifting and spreading history between Rockall and Greenland. The site was abandoned at 489 meters sub-bottom because of torquing in unconsolidated sands. Coring was continuous to total depth.

The section is divisible into three lithologic units and several sub-units. Quaternary to upper Miocene nannofossil oozes, foraminifer nannofossil oozes, and chalks occupy the upper 223 meters of section (Unit 1). A 15-m.y. hiatus separates the upper Miocene and underlying upper Oligocene chalks; it may reflect erosion (or nondeposition) by intensive bottom currents following subsidence of the Iceland-Faeroe Rise. Deposition rates in the upper Miocene reached $38-\mathrm{m} / \mathrm{m}$.y. Unit 2 is 47 meters thick and comprises foraminifer nannofossil chalks of late Oligocene and middle Eocene age. The upper Oligocene chalks, a mere 10 meters thick, are grayish green, whereas the middle Eocene chalks are siliceous and glauconitic. A 3-5-m.y. hiatus may separate the middle and lower Eocene at about 10 meters above the base of the unit. Unit 3, comprising the balance of the recovered section, is a lower Eocene to upper Paleocene series of interbedded volcaniclastics and mudstones of shallow marine deltaic aspect. The oldest sediments penetrated are non-fossiliferous, arkosic sands and sandstones with minor lignitic mudstone and cross-laminated siltstones, of marginal marine or deltaic aspect. Faunal and lithological evidence indicates progressive subsidence of the site from a littoral depth in late Paleocene-early Eocene time to outer shelf depths by middle Eocene, then to depths in excess of 1000 meters by Oligocene time.

\section{Site $\mathbf{4 0 4}$}

Site 404 was drilled three miles southeast of the preceding site, within the same sediment-filled basin on the southwest margin of the Rockall Plateau, in anticipation that the unconsolidated sands that had prematurely terminated drilling at Site 403 would not be encountered. A total of 389 meters of section was penetrated, of which the upper 170 meters were spot cored.

Three lithologic units were apparent and are considered equivalent to those at Site 403. The uppermost, Unit 1, ranges in age from Pleistocene to late Miocene, and consists of a top 28 meters of light brown calcareous mudstone and marly nannofossil and foraminifer nannofossil oozes, of Pleistocene and late Pliocene age. Pebbles of quartz, feldspar, quartzite, hornfels, and granites within this interval suggest ice-rafting. Following an uncored 76 meters, the lower part of Unit 1 consists of 95 meters of lower Pliocene to upper Miocene bluish white nannofossil and foraminifer oozes. Unit 2, 28.5 meters thick, is middle Eocene olive-yellow to dusky green calcareous porcelanites and nannofossil porcelanites; siliceous tuffs and glauconitic mudstones are common and contact with underlying Unit 3 is transitional. Unlike at Site 403 , Oligocene sediments are either absent or were not recovered at Site 404 . The lowermost lithologic unit, Unit 3, at Site 404 consists of 72.5 meters of lower Eocene to probable upper Paleocene siliceous tuffs, tuffaceous porcelanites, and glauconitic siliceous limestones, underlain by 99 meters of tuffaceous mudstones. The lowest 30 meters of Unit 3 contains glauconitic sandstones, conglomerates and lignites; the hole ended in a tuffaceous conglomerate containing a large oyster shell fragment. These rocks indicate a near littoral environment, probably the top of the deltaic sequence but, by middle Eocene time, the site had subsided rapidly to middle bathyal depths. Fresh shards of volcanic glass in the middle Eocene sediments suggest contemporaneous volcanism, possibly on the Iceland-Faeroe Rise.

\section{Site 405}

Site 405 was drilled at the foot of the east-west-trending transform fault which defines part of the southwest margin of the Rockall Plateau. The principal objective of the site (with Site 406) was to examine the structural and stratigraphic evolution of a transform margin also exposed to a subsequent phase of rifting and subsidence as recorded at Sites 403 and 404 . The site was cored continuously to a total sub-bottom depth of 407 meters.

Almost the whole of the Pliocene is unrepresented and a hiatus of about $43 \mathrm{~m} . \mathrm{y}$. was present between the upper Miocene and the middle Eocene. Two lithologic units and six sub-units were recognized. Unit 1 extends from the sea floor to the upper Miocene-middle Eocene hiatus at 65 meters. The unit consists of marly foraminiferal nannofossil ooze and foraminiferal nannofossil ooze. Unit 2 consists in its upper part of foraminiferal nannofossil ooze, nannofossil ooze, and siliceous nannofossil ooze; in its lower part, the principal lithologies are well-laminated siliceous mudstones with interbedded chert layers. The hole terminated in claystones of early Eocene age. Dips of up to $30^{\circ}$ were recorded in these lower Eocene sediments. Benthic foraminiferal assemblages of Eocene age are a mixture of bathyal and upper-slope to shelf species.

\section{Site 406}

Site 406 was situated about 5 miles south of 405 and was drilled to provide with this site a composite stratigraphic record of the history of a transform margin. The hole was 
also designed to penetrate the Pliocene to middle Eocene that was missing at Site 405 . The hole was spot cored to a depth of 413.5 meters and then cored continuously to the final sub-bottom depth of 822.0 meters.

Hiatuses were found between the upper and middle Miocene, within the upper Miocene, between the middle Oligocene and the upper Eocene, and between the upper Eocene and the middle Eocene. Five lithologic units and three sub-units were recognized. Unit $1(0$ to $71.5 \mathrm{~m})$ comprises rhythmically interbedded calcareous mud, marly foraminiferal nannofossil ooze and foraminiferal nannofossil ooze. Unit 2 (110 to $557.5 \mathrm{~m}$ ) consists of foraminiferal nannofossil ooze and chalk of Pliocene to middle Miocene age. Unit 3 (557.5 to $617.5 \mathrm{~m}$ ) of early Miocene to late Oligocene age consists principally of diatomaceous chalk with interbeds of calcareous diatomite. Unit 4 (617.5 to $765.0 \mathrm{~m}$ ), of late Eocene age, is calcareous chalks interbedded with diatomites. Slumping is common within the unit. Unit 5 (765.0 to $822.0 \mathrm{~m}$ ) of middle Eocene age consists of marly calcareous chalk and limestones representing the uppermost part of the fan-like body observed on the seismic profiles.

The lower-middle Eocene sediments drilled at Sites 405 and 406 are interpreted as a large submarine fan built out from the foot of the transform fault in bathyal depths. The hiatuses are tentatively attributed to periods of intensified bottom circulation perhaps associated with wider ocean circulation changes. The alternations of carbonate and diatomite may indicate local upwelling, and the slumping erosion by bottom currents. The thick section of Miocene calcareous ooze is probably the product of sediment drifting. The seismic and paleobathymetric data suggest that $1.6 \mathrm{~km}$ of subaerial relief may have existed along the transform fault. The total relief of about $5.5 \mathrm{~km}$ was apparently created by Eocene time.

\section{EXPLANATORY NOTES}

\section{Responsibility for Authorship}

The authorship of Site Report chapters is collectively the shipboard party with ultimate responsibility lying with the two chief scientists who rewrote much of these chapters. Chapters 3 through 7 present data and discussions on the holes drilled. However, presentation of the Site Reports does not necessarily follow the format established in previous DSDP volumes. In Site Report chapters 6 and 7, Holes 403 and 404, and 405 and 406 on the Rockall Plateau are grouped together. The remaining sites are discussed in individual chapters. All Site Report chapters, however, follow the same general outline (below) with the authorship listed in parentheses.

Site Data and Principal Results

Background and Objectives (Montadert and Roberts)

Operations (Montadert and Roberts)

Lithology (Thompson, Auffret, Kagami, Lumsden, Timofeev, Montadert, Roberts)

Biostratigraphy (Bock, Dupeuble, Müller, Schnitker)

Biostratigraphic Summary

Foraminifers (Schnitker, Bock, Dupeuble)

Calcareous Nannofossils (Müller)

Palynology (taken from shore-lab studies)

Physical Properties (Thompson)
Well Logging (Mann, Roberts)

Correlation of Seismic Reflectors (Montadert, Roberts)

Sedimentation Rates (Müller)

Summary and Conclusions (Montadert, Roberts)

References

In preparing the site chapters, exclusive use has been made of the shore-based studies given in other chapters in this volume. These are fully acknowledged in the text. Contributions by individual shoreside workers to sections of the Site Report also are acknowledged.

Chapters in the volume are grouped under paleontology, sedimentology, organic geochemistry, regional geological studies, and into a series of synthesis chapters designed to provide an overview of passive margin evolution. Shipboard organic and inorganic geochemical data are discussed in the chapters by Harrison and Gieskes.

\section{Superlogs}

The general practice followed in the Initial Reports of the Deep Sea Drilling Project has been to present the basic lithologic data on core forms appended to each site chapter. Smear-slide and quantitative sedimentologic data have usually been tabulated separately and dispersed on the core summary forms. Physical properties data have been treated separately.

The shipboard scientific party felt that more use could be made out of these data and the downhole logs by collectively presenting them on superlogs which are inserted inside the back cover of this volume. In this way, correlations can be directly observed between, e.g., carbonate content, sonic velocity, and gamma-ray values. Lithologic units can be readily discerned using this presentation and subtle changes in lithology presented more obviously. The superlogs have been drawn at a scale of $1 / 200$ to match the optical camera graphic recordings of the downhole logs.

Data presented on the superlogs are as follows:

Age

Biostratigraphic zonation (foraminifers, nannofossils, and radiolarians)

Magnetic susceptibility

Natural remanent magnetization

Grain size

Gamma-ray log

Carbonate

Lithologic units and sub-units

Sub-bottom depth

Core recovery

Core number

Lithologic log

Lithologic description

Drilling rate

Sound speed (perpendicular and parallel to bedding)

Wet bulk density (a) perpendicular and parallel to the bedding from GRAPE, (b) determined by chunk and syringe

Acoustic impedance

Porosity and water content

Whenever possible, the electric logs have been traced onto the superlogs but have been omitted for clarity on the superlog for Site 406 . 


\section{Survey and Drilling Data}

The survey data used for specific site selections are given in each Site Report chapter. On passage between sites, continuous observations were made of depth, magnetic field, and sub-bottom structure. Short surveys were made on Glomar Challenger before dropping the beacon, using a precision echo sounder, seismic profiles, and magnetometer.

Underway depths were continuously recorded on a Gifft precision graphic recorder (PGR). The depths were read on the basis of an assumed 800 fathoms/s sounding velocity. The sea depth (in $\mathrm{m}$ ) at each site was corrected (1) according to the tables of Matthews (1939) and (2) for the depth of the hull transducer $(6 \mathrm{~m})$ below sea level. In addition, any depths referred to the drilling platform have been calculated under the assumption that this level is 10 meters above the water line.

The seismic profiling Teledyne system consisted of two Bolt airguns, a hydrophone array, Bolt amplifiers and filters, and two EDO recorders which had the same filter settings.

\section{Drilling Characteristics}

Since the water circulation down the hole is an open one, cuttings are lost onto the sea bed and cannot be examined. The only information available about sedimentary stratification between cores, other than from seismic data, is from an examination of the behavior of the drill string as observed on the drill platform. The harder the layer being drilled, the slower and more difficult it is to penetrate. However, there are a number of other variable factors which determine the rate of penetration, so it is not possible to relate this directly with the hardness of the layers. The parameters of bit weight and rpms are recorded on the drilling recorder and influence the rate of penetration which is recorded on the superlogs.

\section{Drilling Disturbances}

When the cores were split, many showed signs of the sediment having been disturbed since its deposition. Such signs were the concave downward appearance of originally plane bands, the haphazard mixing of lumps of different lithologies, and the near fluid state of some sediments recovered from tens or hundreds of meters below the sea bed. It seems reasonable to suppose that these disturbances came about during or after the cutting of the core. Three different stages during which the core may suffer stresses sufficient to alter its physical characteristics from those of the in-situ state are: cutting, retrieval (with accompanying changes in pressure and temperature), and core handling.

\section{Shipboard Scientific Procedures}

\section{Numbering of Sites, Hole, Cores, Samples}

Drill site numbers run consecutively from the first site drilled by Glomar Challenger in 1968; the site number is thus unique. A site refers to the hole or holes drilled from one acoustic positioning beacon. Several holes may be drilled a a single locality by pulling the drill string above the sea floor ("mud line") and offsetting the ship some distance (usually $100 \mathrm{~m}$ or more) from the previous hole.
The first (or only) hole drilled at a site takes the site number. Additional holes at the same site are further distinguished by a letter suffix. The first hole has only the site number; the second has the site number with suffix $A$; the third has the site number with suffix B; and so forth. For example, if Site 400 had 3 holes drilled they should be referenced as Site 400 (first hole), Hole 400A (second hole), and Hole 400B (third hole). It is important, for sampling purposes, to distinguish the holes drilled at a site, since recovered sediments or rocks usually do not come from equivalent positions in the stratigraphic column at different holes.

The cored interval is the interval in meters below the sea floor measured from the point at which coring for a particular core was started to the point at which it was terminated. This interval is generally 9.5 meters (nominal length of a core barrel) but may be shorter if conditions dictate. Cores and cored intervals need not be contiguous. In soft sediment, the drill string can be "washed ahead" without recovering core by applying sufficiently high pump pressure to wash sediment out of the way of the bit. In a similar manner, a center bit, which fills the opening in the bit face, can replace the core barrel if drilling ahead in hard sediments without coring is necessary.

The maximum (full) core recovery in a single coring attempt is 9.5 meters of sediment or rock (Figure 3 ). This consists of 9.3 meters in a plastic liner that is held within the core barrel, and 0.2 meter in the core catcher which is screwed onto the lower end of the barrel. When a core is brought onboard, the plastic liner and core are cut in 1.5-meter sections starting from the top of the recovered sediment. A full 9.5-meter core thus consists of six full 1.5-meter sections numbered 1 to 6 from the top down, a short $(0.3 \mathrm{~m})$ Section 7 , and the core catcher at the bottom (see discussion below concerning logging of the core catcher). In the case of partial recovery (Figure 3 ), sections still are measured off and numbered from the top of the recovered sediment, however the number of sections will correspond to the number of 1.5-meter intervals necessary to accommodate the length of core recovered. This may range anywhere from 1 to 6 with the lowermost section usually containing less than 1.5 meters and the core catcher.

On Leg 48, the core-catcher samples were split, then logged on the barrel sheets and stored as an additional increment (maximum $0.2 \mathrm{~m}$ ) of sediment at the bottom of the lowermost section of each core. Despite some contrary opinions, an attempt also was made to maintain the non-conventional designation of $\mathrm{CC}$ for the catcher samples. The full designation of catcher samples from this leg thus includes the number of the lowermost section of the core within which the catcher was logged; for example $400 \mathrm{~A}$ (site and hole) -52 (core number) -5 (section number) - CC.

The cores taken from a hole are numbered sequentially from the top down as the coring proceeds. By DSDP convention, the top of the recovered sediment (top of Section 1) is assigned the depth of the top of the cored interval and any unrecovered sediment is represented as a void at the bottom of the cored interval (Figure 3 ). The core number and its associated cored interval in meters below the sea floor are unique for a hole and are entered into the DSDP computerized data base. 


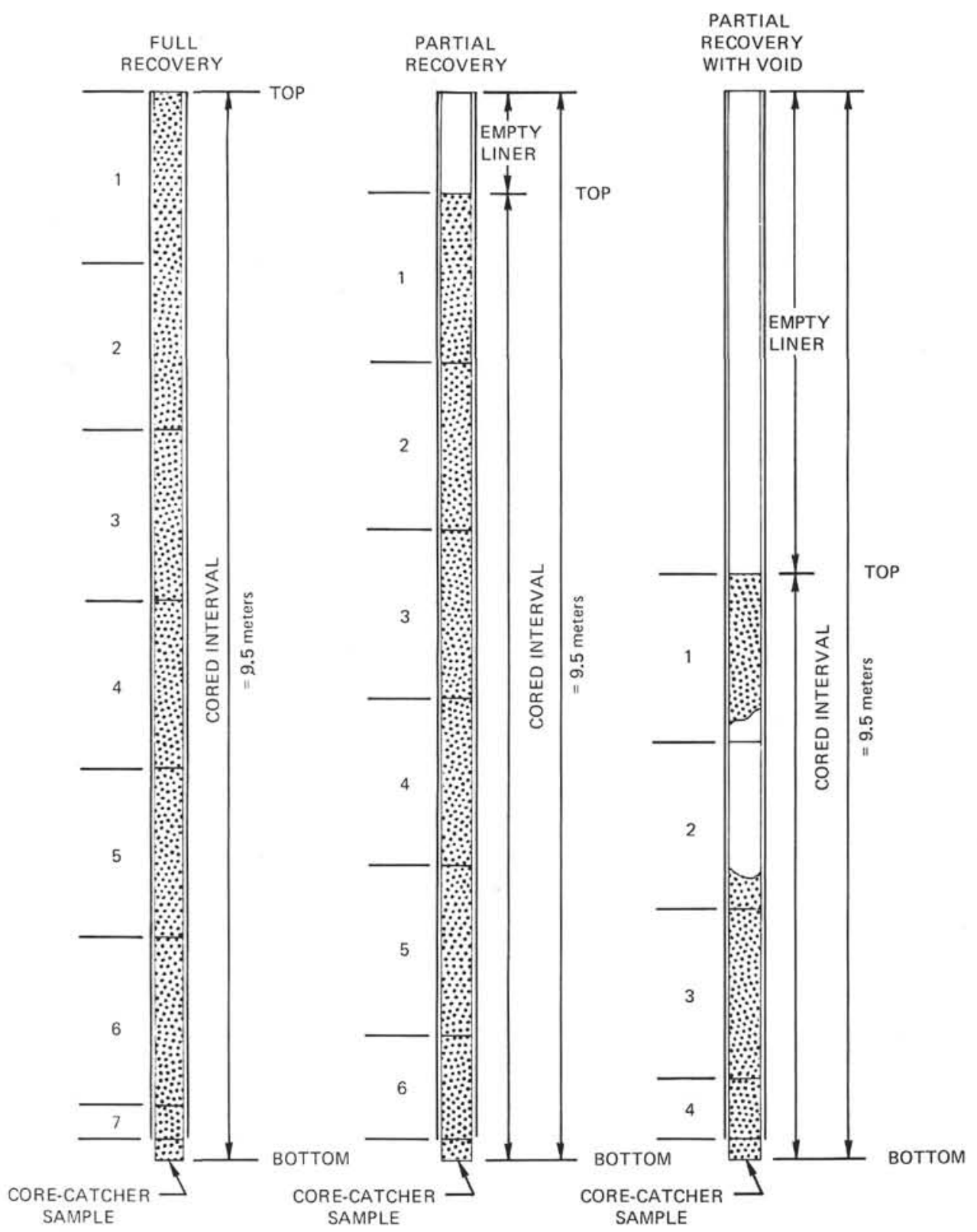

Figure 3. Diagram showing procedure in cutting and labeling of core sections.

In the core laboratory on Glomar Challenger, after routine processing, the 1.5 -meter sections of sediment core and liner are split in half lengthwise. One half is designated the "archive" half, which is described by the shipboard geologists, and photographed; the other is the "working" half, which is sampled by the shipboard sedimentologists and paleontologists for further shipboard and shore-based analyses.

Samples taken from core sections are designated by the interval in centimeters from the top of the core section from which the sample was extracted; the sample size, in $\mathrm{cm}^{3}$, is also given. Thus, a full sample designation would consist of the following information:

Leg (Optional)

Site (Hole, if other than first hole)

Core number
Section number

Interval in centimeters from top of section

Hole $400 \mathrm{~A}-52-3,122-124 \mathrm{~cm}\left(10 \mathrm{~cm}^{3}\right)$ designates a $10-\mathrm{cm}^{3}$ sample taken from Section 3 of Core 52 from the second hole (A) drilled at Site 400. The depth below the sea floor for this sample would be the depth to the top of the cored interval (in this case $559 \mathrm{~m}$ ) plus 3 meters for Sections 1 and 2, plus $122 \mathrm{~cm}$ (depth below top of Section 3), or 563.22 meters.

\section{Core Handling}

The first assessment of the core material was made on samples from the core catcher.

After a core section had been cut, sealed, and labeled, it was brought into the core laboratory for processing. The routine procedure listed below was usually followed: 
1) Weighting of the core section for mean bulk density measurement.

2) GRAPE analysis for bulk density.

3) Sonic velocity determinations.

4) Thermal conductivity measurements.

After the physical measurements were made, the core liner was cut, and the core split into halves by a wire cutter, if the sediment was a soft ooze. If compacted or partially lithified sediments were included, the core was split by a machine band saw or diamond wheel.

One of the split halves was designated a working half. Samples, including those for grain-size, X-ray mineralogy, interstitial water chemistry, and total carbon, organic carbon, and carbonate content were taken, labeled, and sealed. Larger samples were taken from suitable cores for organic geochemical analysis, usually prior to splitting the core. The working half was then sampled for shipboard and shore-based studies.

The other half of a split section was designated an archive half. The cut surface was smoothed with a spatula to emphasize the sedimentary features. The color, texture, structure, and composition of the various lithologic units within a section were described on standard visual core description sheets (one per section), and any unusual features noted. A smear slide was made, usually at $75 \mathrm{~cm}$ if the core was uniform. However, two or more smear slides were often made, for each area of distinct lithology in the core section. The smear slides were examined under a petrographic microscope. The archive half of the core section was then photographed, both in color and in black and white. Both halves were sent to cold storage onboard ship after they had been processed.

Material obtained from core catchers, and not used up in the initial examination, was retained for subsequent work, in freezer boxes. Sometimes significant pebbles from the core were extracted and stored separately in labeled containers.

All samples recovered on Leg 48 are now deposited in cold storage at the DSDP East Coast Repository at Lamont-Doherty Geological Observatory and are available to investigators.

\section{Procedures Used in the Measurement and Presentation of Physical Property Data}

\section{Objectives}

Physical properties data derived from cores help the shipboard selection and interpretations of sediment units and aid correlation of those units with downhole logs and with seismic reflectors, thereby providing a means of extrapolating information beyond the drill sites. With this purpose in mind the two primary objectives consisted of: (1) relating physical properties of cores to lithology, with emphasis on composition and lithification (including compaction and cementation) and (2) correlating lithology to downhole logs.

\section{Sampling and Measurements}

Physical properties determinations on cores (in addition to coring rate) include: temperature, sound speed, wet bulk density, sound impedance, porosity, water content, and a few measurements of shear strength made with the vane shear equipment on uncompacted sediment within the top 160 meters below the ocean bottom. Brief descriptions of procedures for sampling and measurement follow. The reader may consult detailed discussions in the various shipboard manuals and the publication by Boyce (1976).

Understanding relationships among physical properties and lithologies requires close coordination between sample selection and description of lithology while in progress onboard ship; selection of samples to avoid drilling disturbance and fractures; careful preparation of samples; and use of the same interval (of 5 to $10 \mathrm{~cm}$ ), slab, or plug (minicore) for sound speed, bulk density, porosity, and water content as well as $\mathrm{CaCO}_{3}$ content. Immediate calculation of sound speed allowed recognition of changes in lithology, more critical examination of the core, and selection of more samples for definition of key beds that might help correlation with downhole logs. Measurements of sound speed (with the Hamilton Frame) and wet bulk density (by the 2-minute GRAPE method) on two samples per section when plotted relative to depth produced logs with striking accord to the lithologic observations and the downhole logs (see the superlog for Site 406).

Temperature measurements merely involved inserting a thermometer into the sediment of the split liner at the time of sample selection, immediately prior to measurement of sound speed.

Measurements of compressional sound speed with the Hamilton Frame ranged from an average of 2 per core at the beginning of the cruise (Site 400 ) up to 10 per core at the end of the cruise (Site 406). The more frequent measurements reflected delineation of abrupt velocity changes. Techniques included measurement of uncompacted sediment in the split liners, measurement on slabs of compact sediment removed from the liners and squared with a razor or saw, and measurements on plugs (minicores) cut with the drill press.

Except in the uncompacted sediment, sound speeds were determined both parallel and perpendicular to the sediment layers. Measurements both parallel and perpendicular to the beds on 17 samples from the bottom 150 meters of Site 403 showed close agreement (within a few per cent and without any consistent variation) between sound speeds on slabs and plugs taken from the same slabs.

Measurements of wet bulk density utilized the Gamma Ray Attenuation Porosity Evaluator (GRAPE) and the weight/volume procedures in the shipboard chemistry laboratory. Before the cores were split, selected sections, which most nearly filled the plastic liners, were run through the continuous GRAPE equipment. In uncompacted sediment the 2-minute GRAPE measurements utilized metal cylinders (Boyce bottles) or the split plastic liner whereas the weight/volume determinations came from small syringe samples. In compact sediment, 2-minute GRAPE measurements and weight/volume determinations both came from the same slabs or plugs utilized for the sound speed measurements.

The initial procedure was later modified to eliminate measurements perpendicular to the beds. Based on experience from Sites 400,401 , and 402 these extra measurements wasted time because they showed no 
consistent variations from the measurements parallel to the sediment layers.

Determinations of wet bulk density, porosity, and water content in the shipboard chemistry laboratory averaged two per core. These determinations utilized the same samples measured with the Hamilton Frame and with the GRAPE.

\section{Calculations and Data Tables}

Each of the site chapters that follows includes a numerical summary of physical properties determinations plotted relative to core interval and sub-bottom depth, including general lithology and $\mathrm{CaCO}_{3}$. The data tables vary somewhat from chapter to chapter, representing the discontinuance of vane shear measurements after Site 402, measuring the wet bulk density by 2 -minute GRAPE only parallel with the bedding after Site 402, and identifying the type of sample (see the data tables for Sites 405 and 406).

Determinations of sound speed anisotropy and impedance involve simple calculations. The anisotropy appears as a numerical difference between values measured parallel and perpendicular to the sediment layers, and as a percentage difference between the two. Calculations of sound impedance (sound speed $\times$ wet bulk density) include two forms for comparison: one using an average of densities determined by the 2-minute GRAPE and the other using the weight/volume data for density. Both calculations utilize the sound speeds measured parallel to the sediment layers on the assumption that these would most nearly equal in-situ sound speeds, allowing for expectable decrease in sound velocity due to unloading in bringing the core to the surface. This assumption apparently was incorrect for some well-cemented rocks because the sound speeds measured perpendicular to the sediment layers with the Hamilton Frame agreed with the downhole sound speeds also measured perpendicular to the beds (see the superlog for Site 402).

The $\mathrm{CaCO}_{3}$ percentages in the physical properties summaries were derived in the shipboard chemistry laboratory by the carbonate bomb method used on the same samples on which physical properties were derived. At Sites 401 and 402 the $\mathrm{CaCO}_{3}$ percentages determined on the physical properties samples were consistently lower (ranging from a few per cent up to 20 per cent lower) than percentages determined on lithology samples. A variation in drying procedure (a few hours versus 24 hours for lithology and physical property samples, respectively) may have caused this discrepancy.

\section{Downhole Logging}

Downhole logging is perhaps best known for its use in petroleum exploration where it is widely and successfully used in correlation and stratigraphic studies and in the evaluation of formation fluids and lithology. In deep-sea drilling, the importance of logging is both great and obvious in determining in-situ sonic velocities to accurately correlate seismic reflectors with lithology, to compare the shipboard determination of physical properties with those measured in situ, and to determine lithologies in areas of poor recovery. However, with the exception of a few holes drilled in the igneous rocks of the Mid-Atlantic Ridge and some early attempts during DSDP Legs 7 and 8 , there has been no logging in continental margin areas during the history of the Deep Sea Drilling Project.
For Leg 48, the Institute of Oceanographic Sciences of the Natural Environment Research Council for the Department of Energy kindly provided funding for a logging service by Schlumberger Well Services (U.K.) Ltd.

The principles of downhole logging and its practice onboard Glomar Challenger are discussed here to avoid repetition in each site chapter. Interpretations of the downhole logs are given in each site chapter and discussed more fully in a separate chapter.

\section{Principles of Downhole Logging}

The following tools were on board Glomar Challenger for Leg 48:

1) Compensated Neutron Log $(\mathrm{CNL})-33 / 8^{\prime \prime}$ O.D.

2) Sonic $(\mathrm{BHC})-33 / 8$ " O.D.

3) Compensated Formation Density (FDC) - 33/8" O.D.

4) Gamma Ray (GR) - 33\%" O.D.

5) Variable Density Log (VDL) - 33/8" O.D.

6) Induction Resistivity (ISF) - 33/8" O.D.

7) Temperature Log - $1^{11} 11^{\prime \prime}$ O.D.

The brief explanation given below of the principles of operation of each tool is based on Schlumberger Log Interpretation v. I - Principles (1972).

\section{Compensated Neutron Log (CNL) - Porosity Log}

The neutron $\log$ is used principally for the delineation of porous formations and the determination of their porosity.

A radioactive, plutonium-beryllium or americiumberyllium source mounted in the sonde continuously emits neutrons. These neutrons collide with nuclei in the sediment and lose energy with each collision. The quantity of energy lost per collision is dependent on the relative mass of the nucleus with which the neutron collides. The greatest loss occurs when the neutron strikes a hydrogen nucleus. The deceleration of the neutrons is therefore dependent on the amount of hydrogen in the formation. Successive collisions decelerate within microseconds the neutrons to thermal velocities corresponding to energies of around 0.25 electron volts. The neutrons then diffuse randomly without further energy loss until captured by the nuclei of atoms such as hydrogen, silicon, chlorine, etc. On excitation these nuclei emit high energy gamma rays or neutrons.

The CNL measures these neutron activities at detectors, $\mathrm{N}_{1}$ and $\mathrm{N}_{2}$, spaced at 16 and 24 inches from the source (Figure 4). The ratio of the counting rates at these detectors is related to the quantity of hydrogen and hence to the liquid-filled pore space of the formation. The ratio is processed by a surface computer to yield a linearly scaled recording of neutron porosity index that assumes a limestone matrix.

The counting rates at the detectors fluctuate even where the porosity is constant because the collisions are random. The count rates are therefore averaged in a time-constant circuit. The appearance and statistical accuracy of the log are therefore functions of the setting of the time constant and the logging speed. A time constant of 2 seconds and a logging speed of $1800 \mathrm{ft} / \mathrm{hr}$ yield good quality logs.

It should be noted that the CNL detects all of the water in the formation and not the interstitial water alone. For example, it detects water chemically bonded to shales. In such formations, the neutron porosity is greater than the effective porosity. Minor corrections to the CNL for borehole size, 


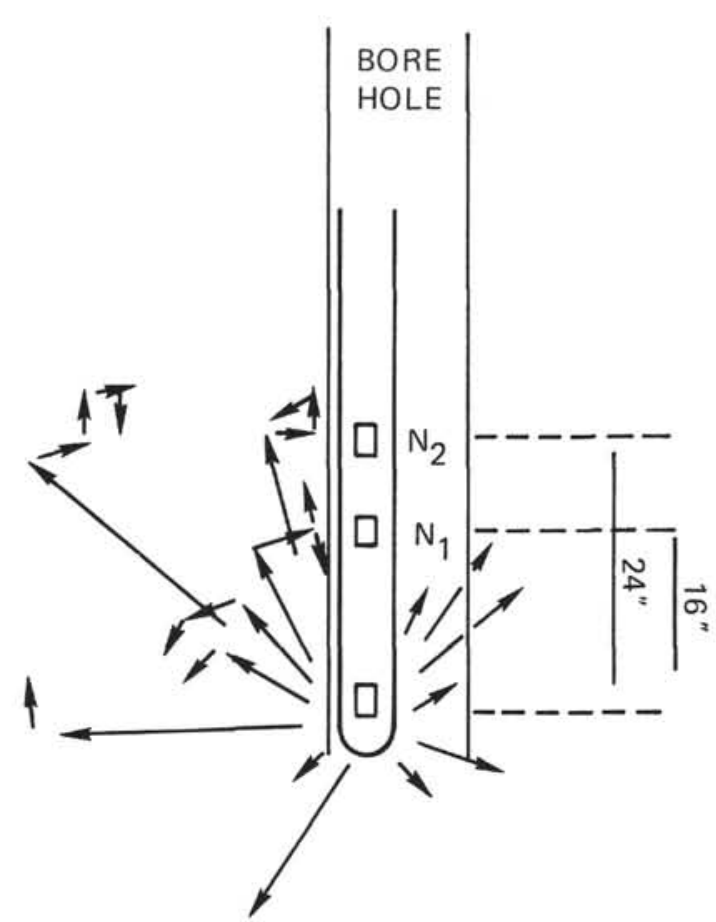

Figure 4. Schematic of the compensated neutron $\log$ used principally for delineation of porous formations.

salinity, temperature, and pressure can be derived from nomograms.

\section{Sonic Log $(B H C)$}

The sonic log is a recording, versus depth, of the time $(\Delta t)$ required for a compressional sound wave to traverse one foot of formation. The interval transit time is the reciprocal of the velocity of the compressional sound wave and is dependent on the lithology and porosity of the formation.

The Borehole Compensated Log (Figure 5) consists of two pairs of receivers with a transducer above and below. The elapsed time between transmission of a sound pulse and detection of the first arrival at the two corresponding receivers are measured continuously. As the speed of sound in the sonde and borehole fluid is less than that of the formation, the first arrival corresponds to a wavelet that has traveled through the formation.

The transducers are pulsed alternately and the $\Delta t$ values read on the pairs of receivers. These values are automatically averaged by computer to cancel errors due to sonde tilt and hole size changes. The transit time is also integrated by computer to give the total travel time to aid seismic interpretation.

Occasionally, a weak first arrival may only trigger the first receiver and the second receiver may be triggered by a later arrival in the same wave train. Spuriously large travel times thus measured in pulse cycles are shown on the sonic curve as excursion towards higher $\Delta \mathrm{t}$ values known as cycle skipping. This phenomenon is likely to occur when the signal is strongly attenuated by unconsolidated or heavily fractured formations.

The $\Delta \mathrm{t}$ data are displayed in units of microseconds per foot together with the gamma and caliper logs. The integrated

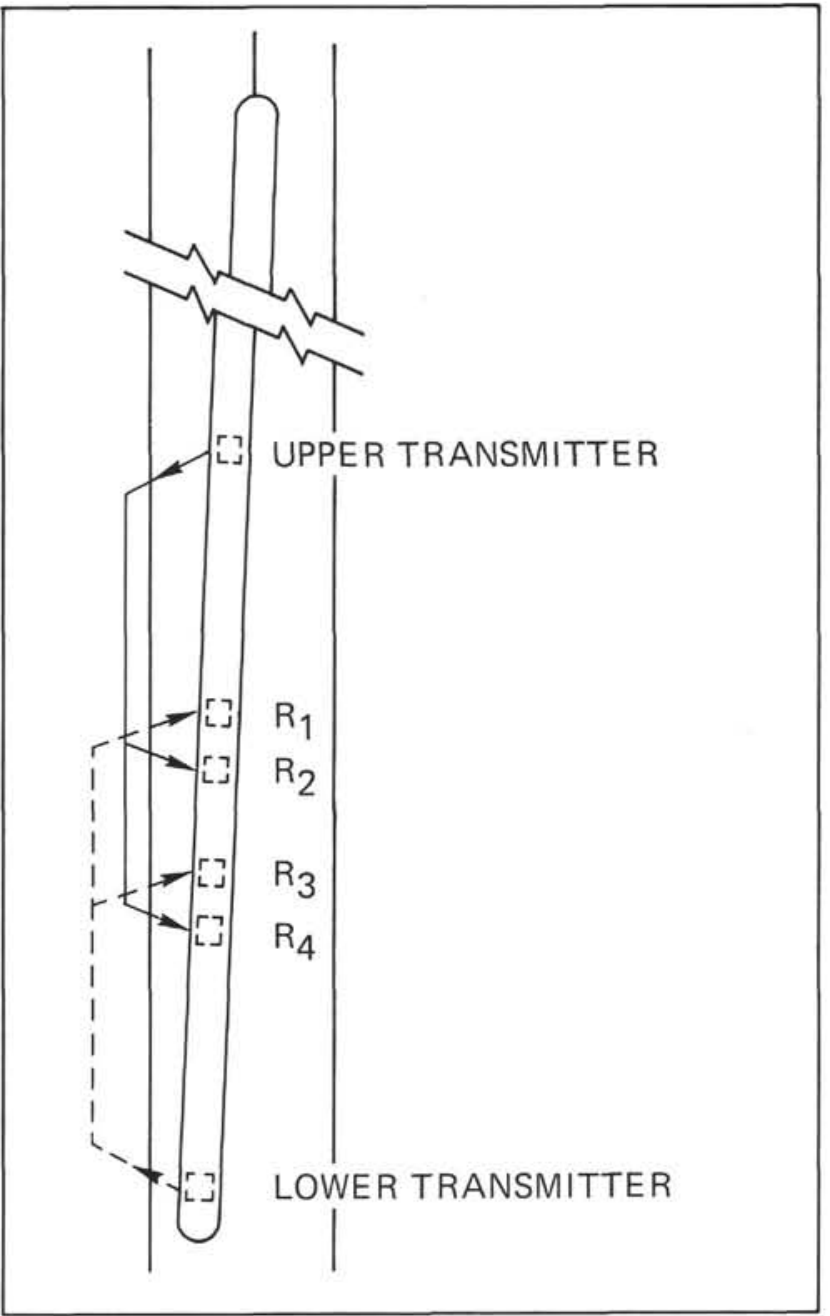

Figure 5. Schematic of BHC sonde, showing ray paths for the two transmitter-receiver sets. Averaging the two $\Delta t$ measurements cancels errors due to sonde tilt and holesize changes.

travel time is given by a series of pips recorded at millisecond intervals.

The transit time data can be used to evaluate porosity (Wyllie, 1956, 1958) according to the relation:

$$
=\frac{\Delta \mathrm{t}_{\log }-\Delta \mathrm{t}_{\mathrm{ma}}}{\Delta \mathrm{t}_{\mathrm{f}}-\Delta \mathrm{t}_{\mathrm{ma}}}
$$

where

$\Delta$ tlog $=$ sonic log value in microseconds per $\mathrm{ft}$,

$\Delta$ tma $=$ transit time of the matrix material,

$\Delta \mathrm{tf}_{\mathrm{f}}=$ about $189 \mathrm{~s} / \mathrm{ft}$ (corresponding to a "fluid velocity" $v_{f}$ of about $5300 \mathrm{ft} / \mathrm{s}$ ).

\section{Compensated Formation Density (FDC)}

The Formation Density Log provides direct measurements of density and is useful as a porosity logging tool. 
The tool consists of a radioactive source which is applied to the borehole wall in a shielded sidewall skid (Figure 6). The source emits medium energy gamma rays which lose energy as they undergo Compton scattering by the electrons in the formation. The number of Compton scattering collisions is related directly to the number of electrons in the formation. Gamma rays reaching the detector at a fixed distance from the source are counted and give a measure of the electron density or number of electrons per cubic centimeter of the formation. Electron density is related to the true bulk density, $\rho_{\mathrm{b}}$ grains $/ \mathrm{cm}^{3}$, which is in turn dependent on the density of the rock matrix material, the formation porosity and the density of the fluid filling the pores.

To minimize the influence of borehole fluids, the source and detector mounted on a skid are shielded. The openings of the shields are applied against the borehole wall by means of an eccentering arm. A correction is needed when the contact between the skid and the formations is poor. In the chart of Figure 7, a plot of long-spacing count rate versus short-spacing count rate is given. Points for a given value of $\rho$ b and various hole conditions fall on or close to an average curve. From these average curves, the corrected $\rho_{b}$ can be derived without any explicit measurement of hole conditions. This correction is made automatically in the FDC and the corrected $\rho_{\mathrm{b}}$ and the correction, $\Delta \rho$, are recorded on the log.

Due to the random scattering, the data exhibit statistical variations that are smoothed before recording by passing the signal through a circuit with a time constant adjustable for formation density. The logging speed is chosen so that the tool will not travel more than one foot during one time constant; the maximum recommended logging speed is 1800 feet per hour.

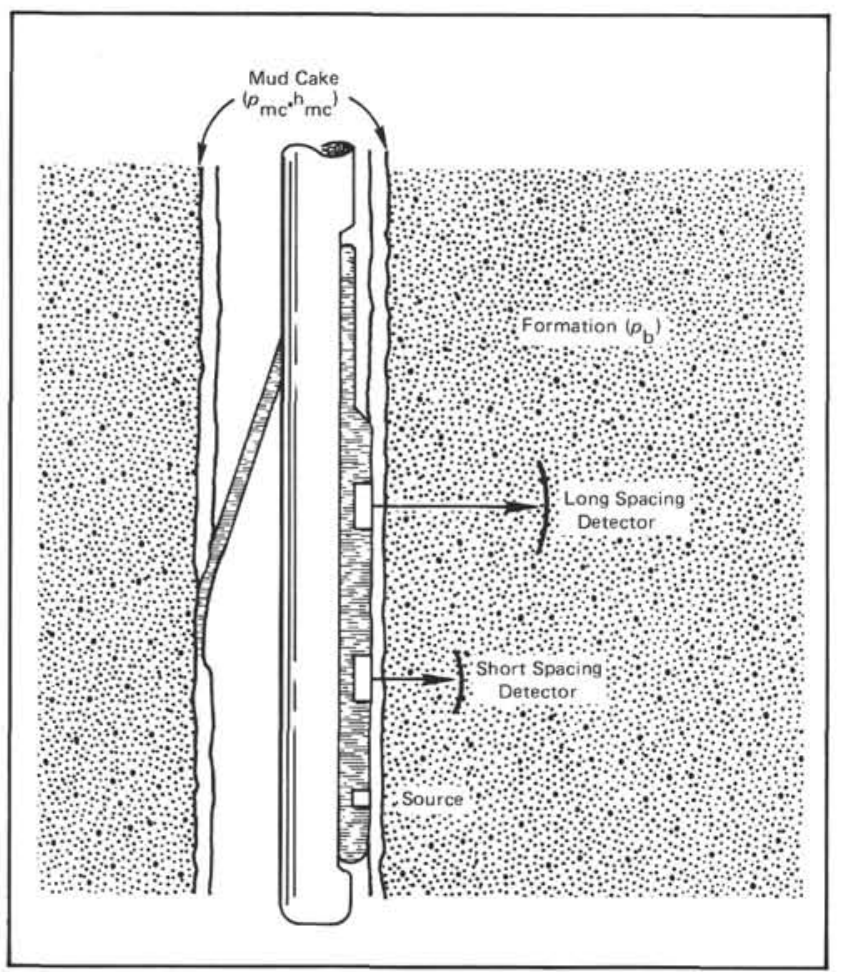

Figure 6. Schematic drawing of the dual spacing Formation Density Logging Device (FDC).

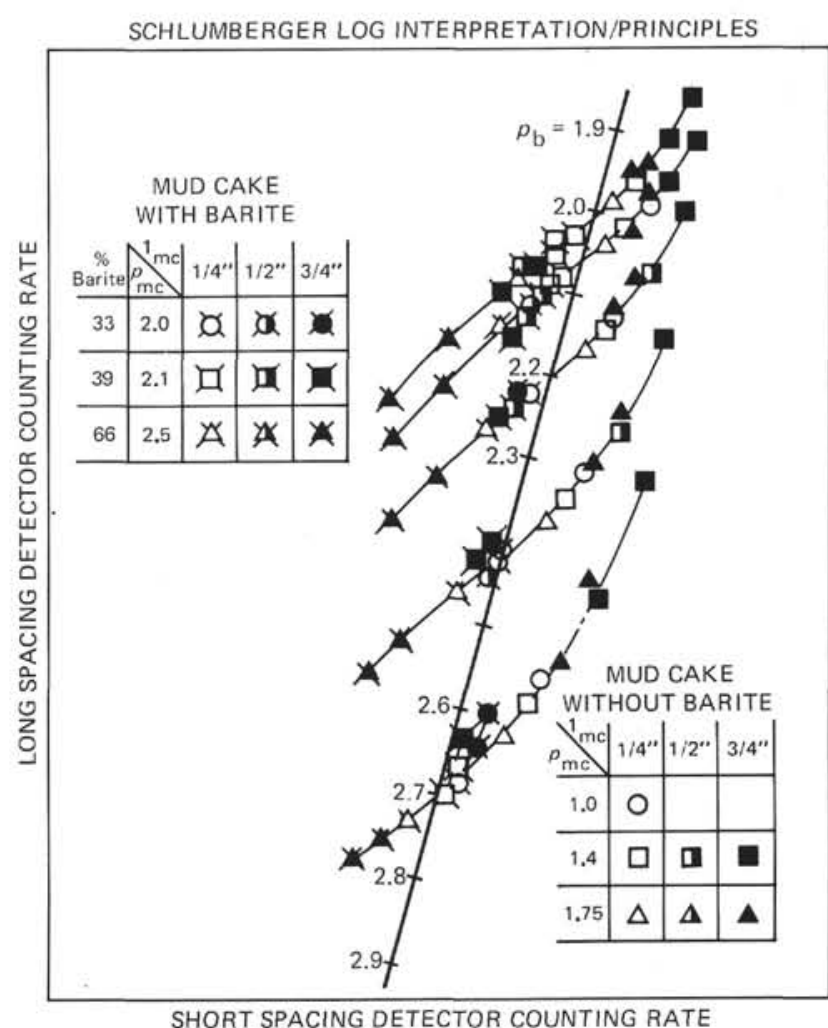

Figure 7. "Spine-and-ribs" plot, showing response of FDC counting rates to mud cake.

The log data are normally presented with the gamma ray and CNL logs. The density log responds to the electron density of the formations and the electron density, $\rho_{\mathrm{e}}$, is proportional to bulk density. For a substance consisting of a single element

$$
\rho_{\mathrm{e}}=\rho_{\mathrm{b}} \frac{(2 \mathrm{Z})}{\mathrm{A}}
$$

where

$\rho_{\mathrm{b}}$ is the actual bulk density,

$\mathrm{Z}$ is the atomic number,

$\mathrm{A}$ is the atomic weight.

For a molecular substance

$$
\rho_{\mathrm{e}}=\rho_{\mathrm{b}} \frac{(2 \mathrm{Z} \text { 's })}{\text { mol.wt. }}
$$

where $\mathrm{Z}$ is the sum of the atomic numbers of the atoms in the molecule.

For a density logging tool, calibrated in a freshwaterfilled limestone formation, it can be shown that

$$
\rho_{\mathrm{a}}=1.0704 \rho_{\mathrm{e}}-0.1883
$$

where $\rho_{\mathrm{a}}=$ apparent bulk density recorded by the tool. For sandstones, limestones, and dolomites, $\rho_{\mathrm{a}}$ is practically identical to the bulk density.

For a clear formation of known matrix density $\left(\rho_{\text {ma }}\right)$, of porosity containing a fluid of average density $\rho_{\mathrm{f}}$, the formation bulk density, $\rho_{b}$ is $\rho_{b}=\rho_{f}+(1-\phi) \rho_{\text {ma. }}$. 
For many pore fluids, the difference between $\rho_{\mathrm{a}}$ and $\rho_{\mathrm{b}}$ is small and $\phi=\frac{\rho_{\mathrm{ma}}-\rho_{\mathrm{b}}}{\rho_{\mathrm{ma}}-\rho_{\mathrm{f}}}$, where $\rho_{\mathrm{a}}=\rho_{\mathrm{b}}$.

\section{Gamma Ray (GR)}

The gamma-ray $\log$ is a measurement of the natural radioactivity of the formations. In sediments, the gamma-ray $\log$ is normally a reflection of shale content because radioactive elements are concentrated in clays and shales. The tool also records the gamma-ray activity of the formation through the casing. During Leg 48, the gamma log was used to correlate between the various logging runs.

The gamma-ray sonde contains a scintillation counter to measure the gamma radiation originating in the volume of the formation near the sonde. The naturally radioactive elements contained within the sediments emit gamma rays whose energies are degraded as they pass through the sediment. The amount of absorption depends on the density of the sediment so that less dense sediments will appear to be more radioactive.

The gamma-ray response after correction for hole conditions (diameter, casing, mud weight, etc.) is proportional to the weight concentration of radioactive material in the formation.

The number of gamma rays reaching the counter fluctuates even when the sonde is stationary due to the statistically random natural emission of gamma rays. To average out these statistical variations, various time constants can be selected to accord with the measured level of radioactivity.

It should be noted that in interpreting the gamma-ray curve, a bed boundary is picked at a point halfway between the maximum and minimum deflection. The recorded depth of this point depends on the logging speed and time constant. For example, the apparent depth is shifted in the direction the tool is moving with an increase in the logging speed or length of time constant. The lag is approximately equal to the distance the counter moves during one time constant.

To avoid excessive distortion of the curve, the recording speed is chosen so that the lag is about one foot. The dynamic measure point of a gamma-ray logging tool is then taken as being located below the counter at a distance equal to the lag. This places the mid-point of a bed-boundary gamma-ray anomaly at the correct depth on the $\log$.

\section{Variable Density Log (VDL)}

The variable density log provides a qualitative record of the variable amplitude of sonic wave trains transmitted by sonic sondes.

The wave train is displayed on an oscilloscope, the light spot of which varies in brightness in proportion to the amplitude of the received acoustic wave. The oscilloscope traces are photographed onto film moving synchronously with the sonde. On the film, amplitude changes are shown by variations in contrast across the film so that dark areas correspond to positive maxima of the wave form.

The amplitude or variable density $\log$ is often used to detect fracture systems in hard formations. In such formations, the amplitude of the wave is much reduced. However, bedding planes and thin shale interbeds may give the same response as fractures so that careful comparison of the logs with core and drilling data is necessary in interpretation. Variations in resistivity and porosity can also determine fracturing.

\section{Induction Resistivity (ISF)}

The induction $\log$ was originally developed to measure formation resistivity in boreholes containing oil-based muds. Induction logging devices are focused to reduce the influence of the borehole and of the surrounding formations.

The induction sonde consists of several transmitter and receiver coils, but the principles can be understood by considering a sonde comprising single transmitter and receiver coils (Figure 8 ).

A high frequency alternating current of constant intensity is sent through the transmitter coil creating an alternating magnetic field that induces secondary currents in the formation. These currents flow in circular ground loop paths coaxial with the transmitter coil. These ground loop currents create magnetic fields which induce a current in the receiver coil. The induced current is proportional to the conductivity of the formations. Any signal produced by direct coupling of transmitter and receiver coils is balanced out by the measuring circuits.

The ISF combination used on Leg 48 included a deep induction tool focused to measure the resistivity of the uninvaded zone of the formation and a shallow spherically focused array to measure the resistivity of the flushed and transition zones near the borehole. The spontaneous potential or difference between the potential of a movable electrode in the borehole and the fixed potential of a surface electrode was also measured to calculate formation water resistivity, salinity, and the presence of permeable beds. A gamma-ray log was also run for calibration purposes.

\section{Operational Aspects of Logging on Glomar Challenger}

Prior to Leg 48, only logging of re-entry holes had been feasible from Glomar Challenger. This was because tools

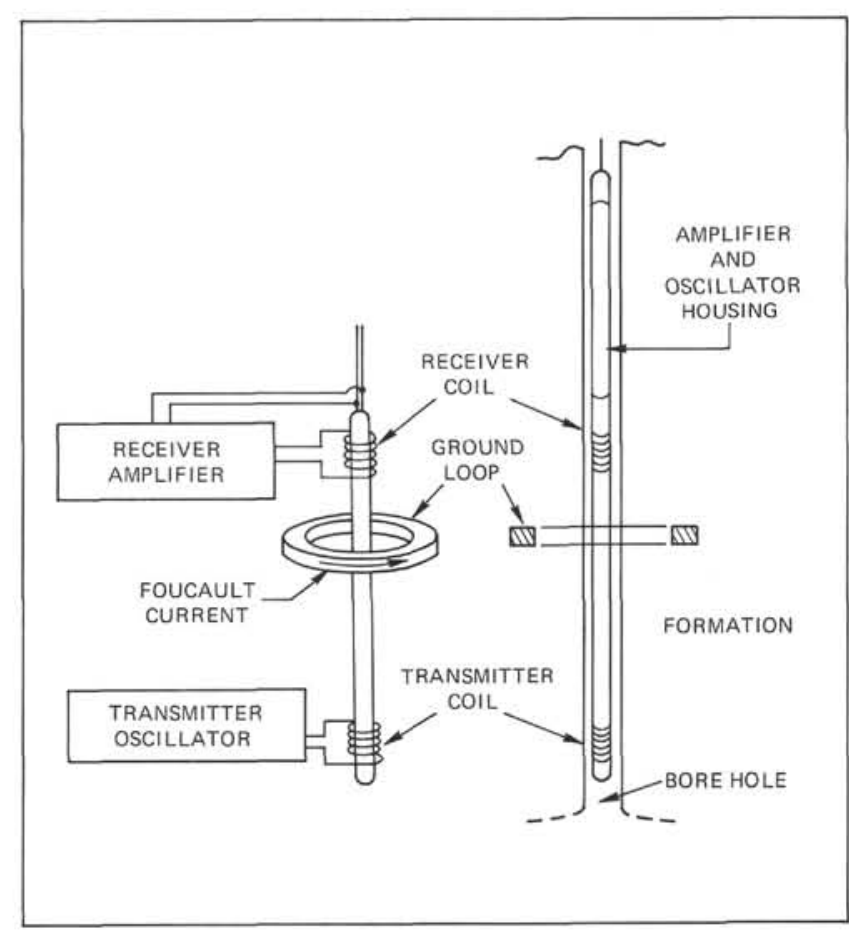

Figure 8. Basic two-coil induction log system. 
slim enough to pass through the bit were not available, and there was no method of releasing the bit in hole to allow passage of the larger diameter conventional logging tools through the drill stem. For Leg 48, Mr. V. Larson, DSDP Operations Manager, developed a special rotary shifting tool to release the bit at the foot of the completed hole, enabling logging of single bit holes.

All the holes drilled during Leg 48 were single bit holes. After termination of drilling, the holes were prepared for logging by spotting mud and then pulling the drill string back to about 100 meters below the sea bed to wipe the hole clean. The drill pipe was then lowered to the terminal depth before the shifting tool was run in to release the bit. After releasing the bit, the drill stem was pulled back to about 100 meters below the sea bed. It was necessary to suspend the drill stem at about this depth to support the bottom hole assembly and bumper subs. In consequence, the upper 100 to 200 meters of single bit holes cannot be logged using this technique.

The logging tools were normally run in the following combinations and order: (1) Gamma, Sonic, Caliper; (2) Gamma, Induction SP; (3) Gamma, Neutron, Density.

The logging tools were so contained as to reduce the number of runs and to utilize the gamma log as a correlator between the various runs. During logging, the optical camera was set to run at speeds of $1 / 200$ and $1 / 1000$. A useful complement to the logging was the compilation, during drilling, of a summary lithostratigraphic and physical properties $\log$ at a $1 / 200$ scale.

During logging operations, a number of problems were encountered that bear relevantly on future logging on Glomar Challenger. The DSDP holes are normally drilled using sea-water circulation. Although the hole was " wiped clean" and mud was spotted before logging, the tools commonly failed to reach total depth (TD) indicating that the hole was slowly filling. In conventional drilling, using mud circulation, a mud cake would be expected to form a lining to the borehole that would prevent sediment sloughing downhole. Apart from preventing the logs from reaching $\mathrm{TD}$, the poor hole conditions frequently caused "bridging" of the hole, requiring spudding by the tool and, on occasions, fresh wiper runs using the drill stem. A serious effect was to jam the caliper necessitating care in interpretation. It was found useful to run the caliper downhole to avoid jamming. In future logging, motorized feeler-type calipers may be more useful.

The reliability of several of the logs, notably the density and neutron logs, is dependent on good borehole conditions. In particular, the hole should be smooth and its diameter should not exceed the 12-inch limit of the eccentralizer used with these tools. Due to jamming, the caliper cannot be reliably used as a check on hole diameter to assess the reliability of these data. However, comparison between these logs, the sonic and resistivity curves, and the small $\Delta \rho$ values suggests that these logs are reliable. The reliability of the variable density log is questionable for the required centralization of $\pm 1 / 8$ is unlikely to have been achieved.

Wave motion is shown as "stair stepping" on the logs. The effectiveness of the heave compensator in eliminating or reducing wave motion is doubtful and complicated by the absence of a fixed point of reference once the drill pipe is off the bottom. It should be noted that the 36-inch sheave required by the bending diameter of the Schlumberger cable is too large to be used with the heave compensator. The effects of the heave compensator on logging speed and thus sensor resolution are likely to be variable. A useful addition to the suite of logging tools would be a dipmeter. Taping of the logs is considered to be an essential part of any logging program on Glomar Challenger. Data recorded on tape can be played back in any combination of depth and scale and processed using computer and visual display techniques. Depth adjustments and correlations between logs can be carried out more easily. In the poor hole conditions at Site 405 for example, the operation of the tools at their limits has resulted in saturation of the analog curves. However, the real data are preserved on tape and can be redisplayed by playback.

It should be noted that depths of the lithostratigraphic log derived from the drillers are usually deeper than those recorded on the electric logs. The magnitude of the discrepancy varies downhole to a maximum of about 9 meters. At Site 406, for example, the formation correlation is +9 meters, the drill stem +5.5 meters, and the sea bed +3 meters. These discrepancies have several causes. The disagreement in the sea bed depth arises from small errors $( \pm 1 \mathrm{~m})$ in (reading) the echo sounder and the equivocal depth of the first core cut at the sea bed; tidal effects may cause a further discrepancy of \pm 1 meter. There are also cumulative errors that arise from the measurement of drill pipe lengths and the uncertain position of the core recovered in each cored interval. Drilled depths determined with the bumper subs closed are also at variance with the drill stem depth determined with the bumper subs open. The problem of correlation between cores and logs could be considerably reduced by routine measurement of the natural gamma-ray activity of the cores using a scanning scintillometer in the laboratory.

In presenting the logs, no attempt has been made to remove these discrepancies and the lithostratigraphic and electric logs are displayed relative to a common sea floor datum.

Copies of the logs run on Leg 48 may be obtained by writing to the Associate Chief Scientist, Science Services, Deep Sea Drilling Project A-031, University of California at San Diego, La Jolla, California 92093.

\section{Geochemical Measurements}

Aboard ship, analyses for $\rho \mathrm{H}$, alkalinity, and salinity are conducted routinely.

$\rho \mathrm{H}$ is determined by two different methods. One is a flow-through electrode method, the other is a punch-in electrode method. $\rho \mathrm{H}$ is determined on all samples via the flow-through method, which is a glass capillary electrode in which a small portion of unfiltered pore water is passed. In the softer sediments a "punch-in" $\rho \mathrm{H}$ is also determined by inserting $\rho \mathrm{H}$ electrodes directly into the sediment at ambient temperature prior to squeezing. The $\rho \mathrm{H}$ electrodes for both methods are plugged into an Orion digital millivolt meter.

Alkalinity is measured by a colorimetric titration of a $1-\mathrm{ml}$ aliquot of interstitial water with $0.1 \mathrm{~N} \mathrm{HCl}$ using a methyl red/blue indicator.

Alkalinity $(\mathrm{meq} / \mathrm{kg})=(\mathrm{ml} \mathrm{HCl}$ titrated $) \cdot(97.752)$ 
Salinity is calculated from the fluid refractive index as measured by a Goldberg optical refractometer, using the ratio:

$$
\text { Salinity }(\% 0)=(0.55) \cdot \Delta N
$$

where $\Delta N=$ refractive index difference $\times 10^{4}$. Local surface sea water is regularly examined by each of the above methods for reference.

\section{Quantitative Sedimentologic Analyses}

\section{Smear Slides}

The lithologic classification of sediments is based on visual estimates of texture and composition in smear slides made onboard ship. These estimates are of areal abundances on the slide and may differ somewhat from the more accurate laboratory analyses of grain-size, carbonate content, and mineralogy. Experience has shown that distinctive minor components can be accurately estimated ( \pm 1 or $2 \%$ ), but that an accuracy of \pm 10 per cent for major constituents is rarely attained. Carbonate content is especially difficult to estimate in smear slides, as is the amount of clay present. Smear-slide analyses at selected levels as well as averaged analyses for intervals of uniform lithology are given on the core description sheets. For carbonate content, reference should be made to shipboard carbonate bomb analyses and shore-based analyses (see below).

\section{Carbonate Data}

During Leg 48, extensive use was made of the carbonate bomb device as an aid in sediment classification onboard ship. This device is basically a cylindrical vessel with pressure gauge in which a sediment sample of known weight is reacted with acid. The pressure of $\mathrm{CO}_{2}$ generated is measured and converted to per cent carbonate. Accuracy to within \pm 5 per cent total carbonate has been quoted for the device.

Samples were taken for DSDP shore-based carbon-carbonate analysis using the LECO 70-Second Analyzer. Results of these analyses are shown on the superlogs.

\section{X-Ray Mineralogical Analyses}

X-ray mineralogical analyses of Leg 48 sediments were provided by the Société Nationale ELF Aquitaine in Pau, France for the Biscay sites, and by the Centre dé Recherches sur l'Environnement (Prof. M. Vigneaux, Directeur) of the Université de Bordeaux for the Rockall sites. Analyses by SNPA were made on powdered bulk samples and comparisons of peak areas yielded percentages of quartz, calcite, dolomite, and anhydrite to an estimated accuracy of \pm 10 per cent. Amounts of feldspar and siderite were estimated qualitatively. Two types of analyses were conducted at Bordeaux: (1) bulk samples were pulverized and analyzed by powder diagrams. Comparison to synthetic reference samples yielded semiquantitative estimates of quartz, calcite, dolomite, and feldspar (alkali and plagioclase); and (2) clay fractions $(<2 \mu \mathrm{m})$ were analyzed by standard techniques and semiquantitative estimates of the various clay minerals (smectite, illite, kaolinite, chlorite) and nonclay minerals (cristobalite-tridymite, zeolite) were made by comparison of peak heights.

The analyses have been incorporated on the superlogs.

\section{Sediment Induration}

The determination of induration is highly subjective, but field geologists have successfully made similar distinctions for many years. The criteria of Moberly and Heath (1971) are used for calcareous deposits; subjective estimate or behavior in core cutting is used for others.

a) Calcareous sediments

Soft: Oozes have little strength and are readily deformed under the finer or the broad blade of a spatula.

Firm: Chalks are partly indurated oozes; they are friable limestones that are readily deformed under the fingernail or the edge of a spatula blade.

Hard: Cemented rocks are termed limestones.

b) The following criteria are used for other sediments: If the material is soft enough that the core can be split with a wire cutter, the sediment name only is used (e.g., silty clay; sand).

If the core must be cut on the band saw or diamond saw, the suffix "stone", is used (e.g., silty claystone; sandstone).

\section{Lithologic Classification}

The lithologic classification scheme used on Leg 48 is basically that devised by the JOIDES Panel on Sedimentary Petrology and Physical Properties and adopted for use by the JOIDES Planning Committee in March 1974. The classification is descriptive and sediment/rock names are defined solely on the basis of composition and texture, primarily as determined from smear slides, bomb analyses, or under the hand lens onboard ship. The classification is outlined below and summarized in Figure 9. Symbols utilized to represent the various sediment types on core description sheets are shown in Figure 10.

I. Pelagic Clay $<10 \%$ authigenic components $<30 \%$ siliceous microfossils $<30 \% \mathrm{CaCO}_{3}$ $<30 \%$ terrigenous components

II. Pelagic Siliceous Biogenic Sediments $>30 \%$ siliceous microfossils $<30 \% \mathrm{CaCO}_{3}$ $<30 \%$ terrigenous components (mud)

Radiolarians dominant: radiolarian ooze (or radiolarite)

Diatoms dominant: diatom ooze (or diatomite)

Sponge spicules dominant: sponge spicule ooze (or spiculite)

Where uncertain: siliceous (biogenic) ooze (or chert, porcelanite)

When containing 10 to 30 per cent $\mathrm{CaCO}_{3}$ : modified by nannofossil-...-, foraminiferal-.-.-, calcareous-----, nannofossil-foraminiferal--.--, or foraminiferal-nannofossil-----, depending upon kind and quantity of $\mathrm{CaCO}_{3}$ component. 


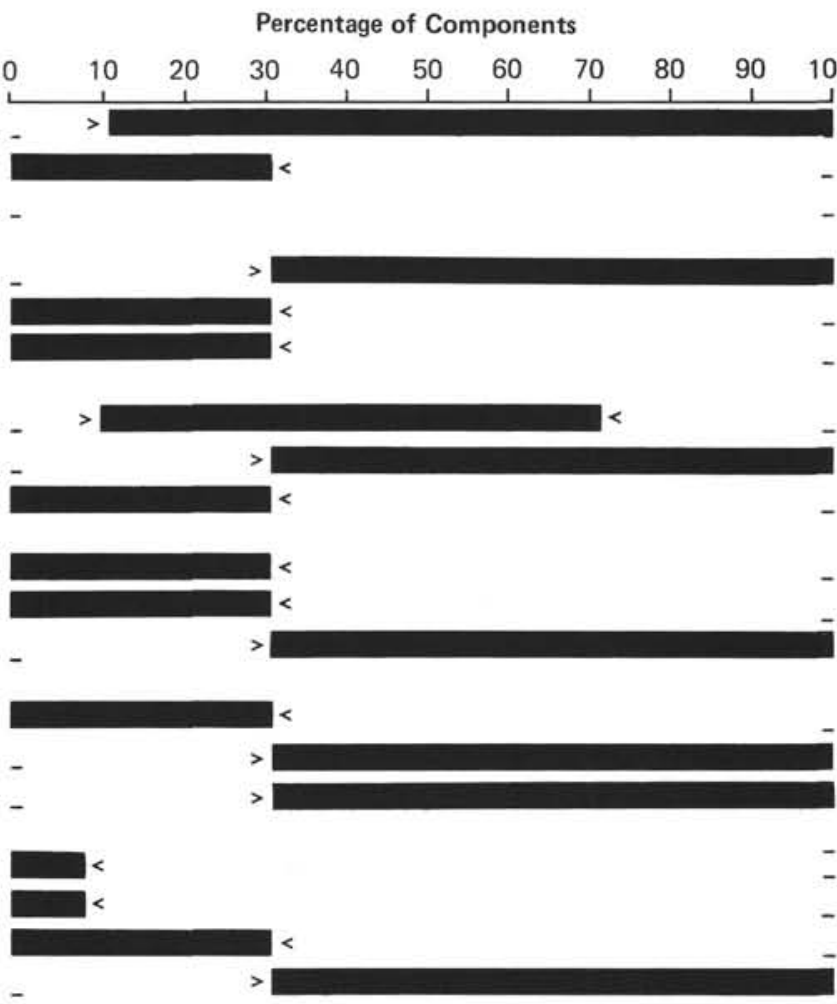

Nomenclature

Component

Sediment Type

Authigenic Components

Siliceous Skeletons

Pelagic Clay (a)

- $\mathrm{CaCO}_{3}$ (See text)

Siliceous Skeletons

Silt and Clay

$\mathrm{CaCO}_{3}$

Pelagic Biogenic Siliceous

(b)

Siliceous Skeletons

Silt and Clay

$\mathrm{CaCO}_{3}$

Siliceous Skeletons

Silt and Clay

$\mathrm{CaCO}_{3}$

Siliceous Skeltons

Silt and Clay

$\mathrm{CaCO}_{3}$

Transitional Biogenic

Calcareous (e)

- Authigenic Components

- $\quad$ Siliceous Skeletons

$\mathrm{CaCO}_{3}$

Transitional Biogenic Siliceous (c)

Pelagic Biogenic Calcareous (d)

Terrigenous and Volcanic Detritus

Terrigenous Sediments $(f)$
(a) See descriptive notes in text
(b) Soft - oozes; Hard - radiolarite, diatomite, chert, or porcellanite
(c) Less than $50 \%$ siliceous fossils - diatomaceous (radiolarian) mud or mudstone
Greater than $50 \%$ siliceous fossils - muddy diatom (radiolarian) ooze or muddy diatomite (radiolarite)
Greater than $10 \% \mathrm{CaCO}_{3}$ - calcareous
(d) Soft - ooze; Firm - chalk; Hard - indurated chalk, limestone
(e) Soft - marly calcareous ooze; Firm - marly chalk; Hard - marly limestone
(f) Soft - clay, mud, silt, sand; Hard - claystone, mudstone, shale (if fissile), siltstone, sandstone
For pyroclastic sediments see text.

Figure 9. Summary chart of lithologic classification for oceanic sediments.

III. Transitional Biogenic Siliceous Sediments

$10-70 \%$ siliceous microfossils

$30-90 \%$ terrigenous components (mud)

$<30 \% \mathrm{CaCO}_{3}$

If diatoms < mud: diatomaceous mud (stone)

If diatoms > mud: muddy diatom ooze (muddy diatomite)

If $\mathrm{CaCO}_{3} 10$ to 30 per cent: appropriate qualifier is used (See III).

IV. Pelagic Biogenic Calcareous Sediments

$$
\begin{aligned}
& >30 \% \mathrm{CaCO}_{3} \\
& <30 \% \text { terrigenous components } \\
& <30 \% \text { siliceous microfossils }
\end{aligned}
$$

Principal components are nannofossils and foraminifers; qualifiers are used as follows:

$\begin{array}{cl}\frac{\text { Foram (\%) }}{<10} & \text { Name } \\ 10-25 & \text { foraminiferal-nannofossil ooze } \\ 25-50 & \text { nannofossil-foraminiferal ooze }\end{array}$

$>50$ foraminiferal ooze

Calcareous sediment containing 10 to 30 per cent siliceous fossils carry the qualifier radiolarian, diatomaceous or siliceous, depending upon the identification.

V. Transitional Biogenic Calcareous Sediments

$>30 \% \mathrm{CaCO}_{3}$

$>30 \%$ terrigenous components

$<30 \%$ siliceous microfossils

If $\mathrm{CaCO}_{3} 30$ to 60 per cent; marly is used as a qualifier:

soft: marly calcareous (or nannofossil, etc.) ooze

firm: marly chalk (or marly nannofossil chalk, etc.)

hard: marly limestone (or marly nannofossil limestone, etc.)

If $\mathrm{CaCO}_{3}>60$ per cent:

soft: calcareous (or nannofossil, etc.) ooze

firm: chalk (or nannofossil chalk, etc.) 
Pelagic

Non-biogenic

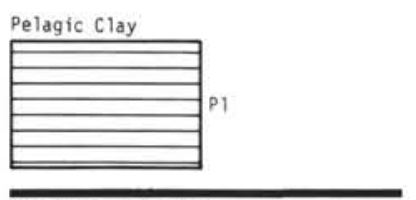

Stliceous Biogenic

Pelagic Siliceous Biogenic - Soft

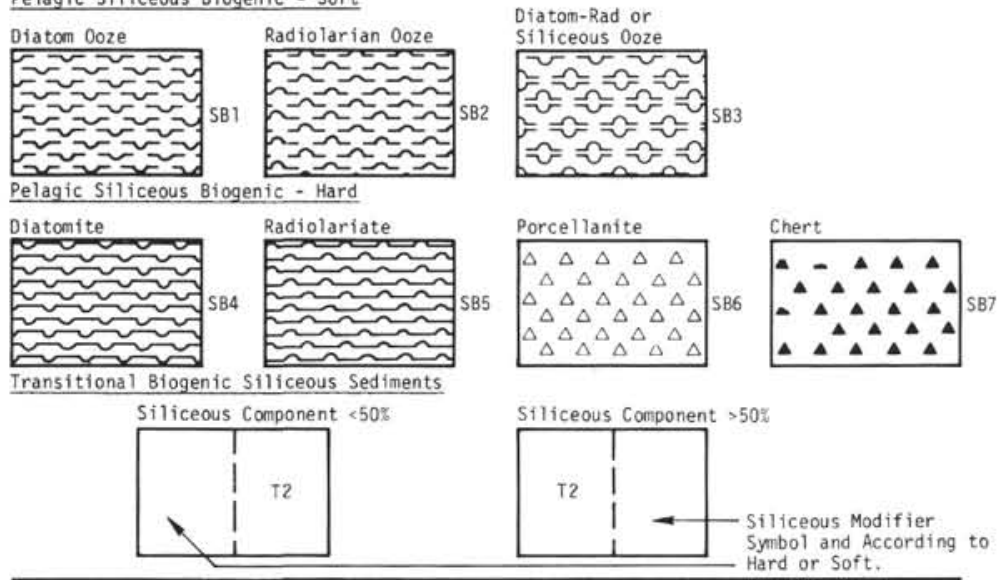

Calcareous Biogenic

Pelagic Biogenic Calcareous - Soft

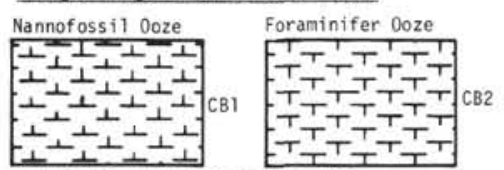

Pelagic Biogenic Calcareous - Firm

Nannofossil Chalk

Pelagic Biogenic Calcareous - Hard

Limestone

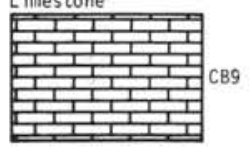

Terrigenous Sediments
Strip system used in graphic logs to ind
of important minor components $(10-50 \%)$.
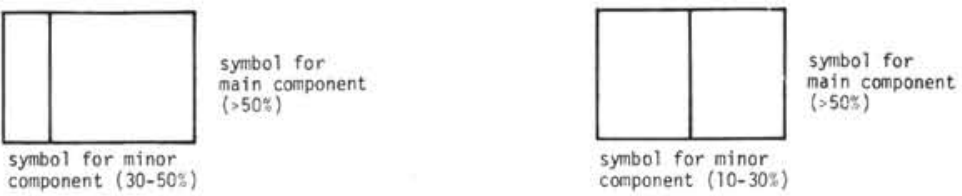
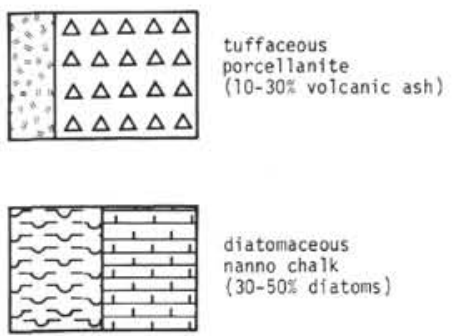

Transitional Biogenic Calcareous Sediments (Examples)

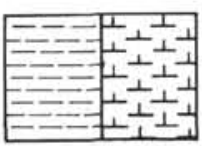

Marly Nanno

Doze

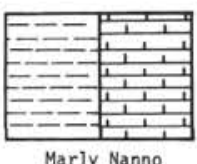

Marly Nann
Chalk

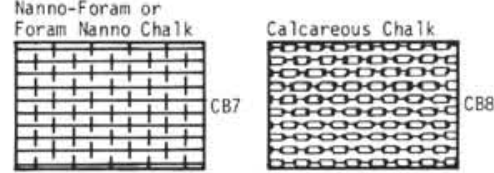

Iransitional Biogenic Calcareous Sediments

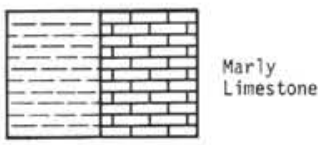

Clay/Claystone

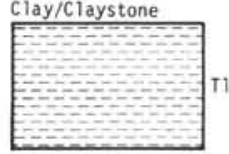

Silty Sand/

Sandy Silt

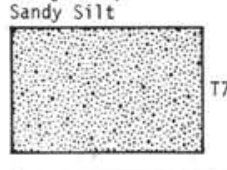

.

Pyroclastic

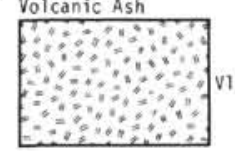

Special Rock Types
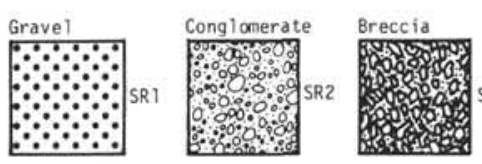

Basic
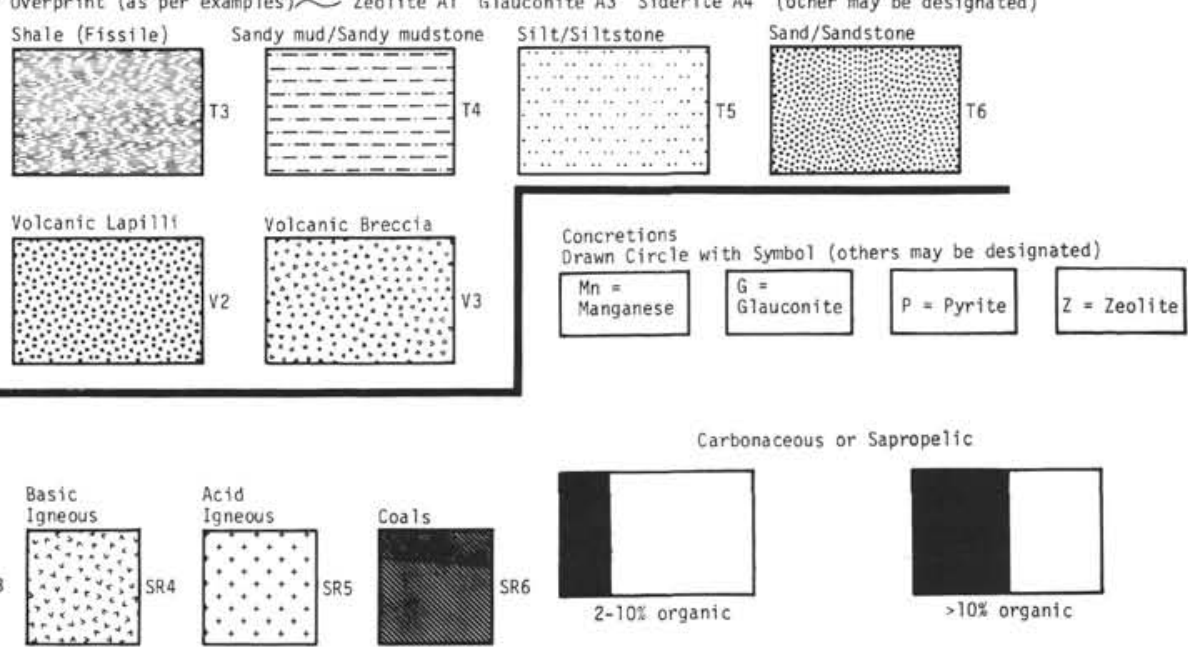

Carbonaceous or Sapropelic

Figure 10. Key to lithologic and biostratigraphic symbols.
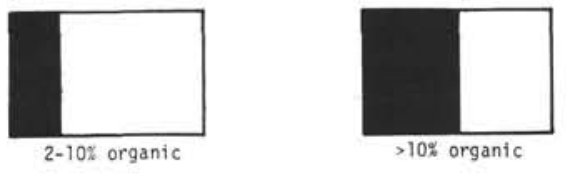
hard: limestone (or nannofossil limestone, etc.)

NOTE: Sediments containing 10 to 30 per cent $\mathrm{CaCO}_{3}$ fall in other classes where they are denoted with the adjective "calcareous," " nannofossil," etc.

VI. Terrigenous Sediments

$$
\begin{aligned}
& >30 \% \text { terrigenous components } \\
& <30 \% \mathrm{CaCO}_{3} \\
& <10 \% \text { siliceous microfossils } \\
& <10 \% \text { authigenic components }
\end{aligned}
$$

Sediments in this category are subdivided into textural groups on the basis of the relative proportions of three grain-size components, i.e. sand, silt and clay. Sediments coarser than sand-size are treated as "'Special Rock Types." The size limits are those defined by Wentworth (1922). The textural classification is according to the triangular diagram shown in Figure 11. The suffix "-stone" is used to indicate hard or consolidated equivalents of the unconsolidated sediments.

If $\mathrm{CaCO}_{3}$ is 10 to 30 per cent: calcareous, nannofossil, etc. is used as a qualifier.

Other qualifiers (e.g., feldspathic, glauconitic, tuffaceous, etc.) are used for components $>10$ per cent.

VIII. Volcanogenic Sediments

A. Pyroclastic rocks are described according to the textural and compositional scheme of Wentworth and Williams (1932). The textural groups are:

Volcanic breccia $>32 \mathrm{~mm}$

Volcanic lapilli $<32 \mathrm{~mm}$

Volcanic ash (tuff, if indurated) $<4 \mathrm{~mm}$

Compositionally, these pyroclastic rocks are described as vitric (glass), crystal, or lithic.

B. Clastic sediments of volcanic provenance are described in the same fashion as the terrigenous

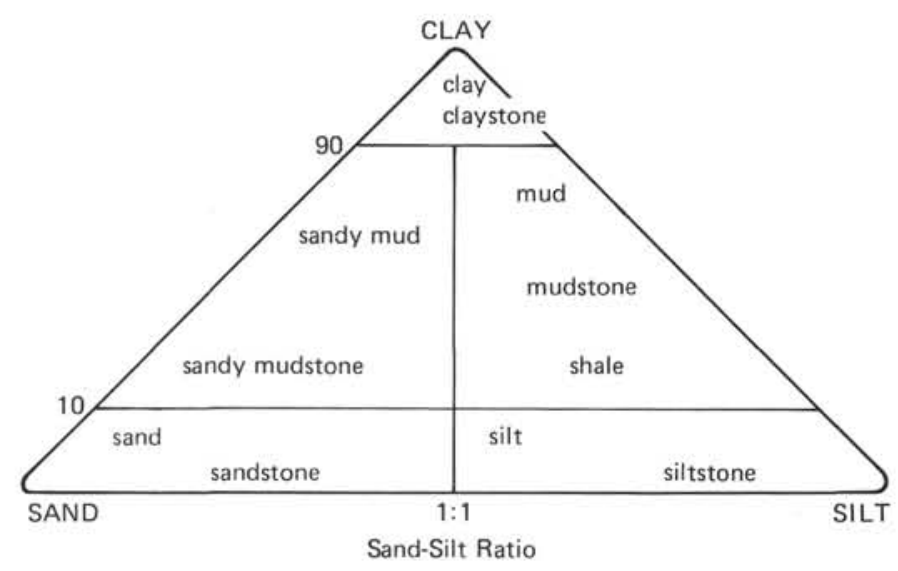

sediments, noting the dominant composition of the volcanic grains where possible.

IX. Special Rock Types

A. The limestones cored at Site 401 (Cores 19-28) are classified according to system of Dunham (1962). In this system, the main rock is assigned according to the following scheme:

\begin{tabular}{l|l|l|l|l|l}
\hline & \multicolumn{2}{|c|}{ Micrite Dominated } & \multicolumn{3}{c}{$\begin{array}{c}\text { Spar and Void } \\
\text { Dominated }\end{array}$} \\
\hline Interstices & \multicolumn{2}{|c|}{ Mud Supported } & \multicolumn{2}{|c|}{$\begin{array}{c}\text { Grain } \\
\text { Supported }\end{array}$} & $\begin{array}{l}\text { Con- } \\
\text { structed }\end{array}$ \\
\hline $\begin{array}{l}\text { Gramework } \% \\
\text { Name }\end{array}$ & $\begin{array}{l}\text { L10\% grains } \\
\text { Lime Mud- } \\
\text { stone }\end{array}$ & $\begin{array}{l}>10 \% \text { grains } \\
\text { Wackestone }\end{array}$ & $\begin{array}{l}\text { Pack- } \\
\text { stone }\end{array}$ & $\begin{array}{l}\text { Grain- } \\
\text { stone }\end{array}$ & $\begin{array}{l}\text { Bound- } \\
\text { stone }\end{array}$ \\
\hline
\end{tabular}

Each rock name is then modified with appropriate terms in order of increasing significance; for example, a pellet intraclast grainstone contains more intraclasts than pellets and these grains are in mutual contact while the interstices are either empty or filled with sparry calcite cement. In the Site 401 cores, the intraclasts are mainly algal lumps (algal bound or coated grains); most of the pellets are probably micritized fossils.

B. Carbonaceous Sediments

Sediments (mudstones, chalks, etc.) containing substantial amounts of detrital plant remains were encountered at Hole 400A and Site 402. These sediments are indicated as carbonaceous if smear-slide determinations showed the organic content to be greater than 2 per cent and/or the carbon-carbonate analyses showed greater than 1 per cent by weight of organic carbon.

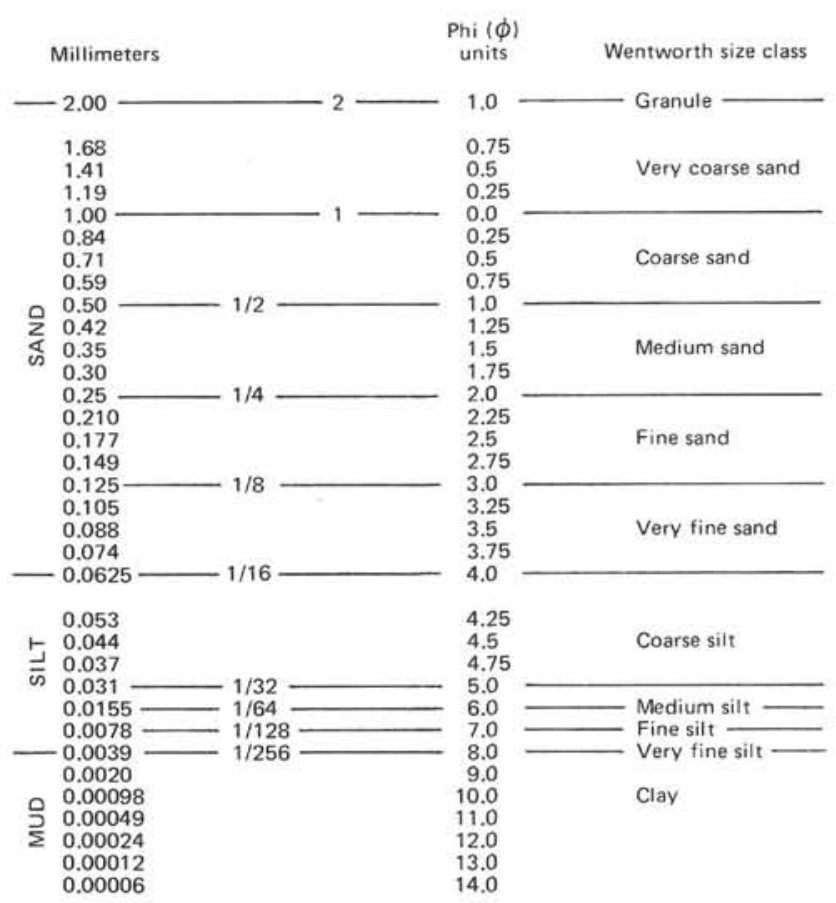

Figure 11. Terminology and class intervals for grade scales. Textural groups-terrigenous sediments. 
C. Silicified Sediments

At Site 405 , much of the calcareous mudstone obtained in Cores 31 to 43 contains in excess of 10 per cent opaline silica which is not in the form of recognizable microfossils. Very hard layers in this section are classified as chert whereas the somewhat softer portions are termed silicified mudstone. The latter are indicated graphically by utilizing the chert symbol in only a fraction of the lithology column. These sediments are thus distinguished from those indicated as siliceous wherein greater than 10 per cent of recognizable siliceous microfossils are present, and for which the porcelanite symbol was used.

\section{Core Disturbance}

Unconsolidated sediments are often quite disturbed by the rotary drilling/coring technique, and there is a complete gradation of disturbance style with increasing sediment induration. An assessment of degree and style of drilling deformation is made onboard ship for all cored material, and shown graphically in a separate column on the core description sheets. The following symbols are used:

- - - - Slightly deformed; bedding contacts slightly bent.

- - Moderately deformed; bedding contacts have undergone extreme bowing.

Highly deformed; bedding completely disturbed, often showing symmetrical diapir-like structures.

$\bigcirc \bigcirc \bigcirc$ Soupy, or drilling breccia; water-saturated intervals that have lost all aspects of original bedding and sediment cohesiveness.

Consolidated sediments and rocks seldom show much internal deformation, but are usually broken by drilling into cylindrical pieces of varying length. There is frequently no indication if adjacent pieces in the core liner are actually contiguous or if intervening sediment has been lost during drilling. The symbolOO was used for cylindrical pieces of core separated by intervals of drilling breccia or injected (remolded) softer sediment. In some cases (notably Site 400 ) fragments of previously drilled material have sloughed back down the hole and been recored. Such material is indicated by the symbol $(0 \bigcirc \diamond)$ and labeled as cavings.

\section{Sedimentary Structures}

Megascopic sedimentary structures are apparent in many of the cored sediments. These include primary features such as lamination, graded bedding, and bioturbation as well as secondary features such as microfaulting. Where it is reasonably certain that these features are not the product of coring disturbance, they are logged graphically in a separate column on the core description sheets utilizing the symbols shown in Figure 12. Caution should be used in drawing conclusions based on the sedimentary structures because it is often extremely difficult to differentiate between natural structures and those produced by coring.

\section{Core Description Forms}

The basic lithologic and biostratigraphic data are summarized on core description forms (barrel sheets) which

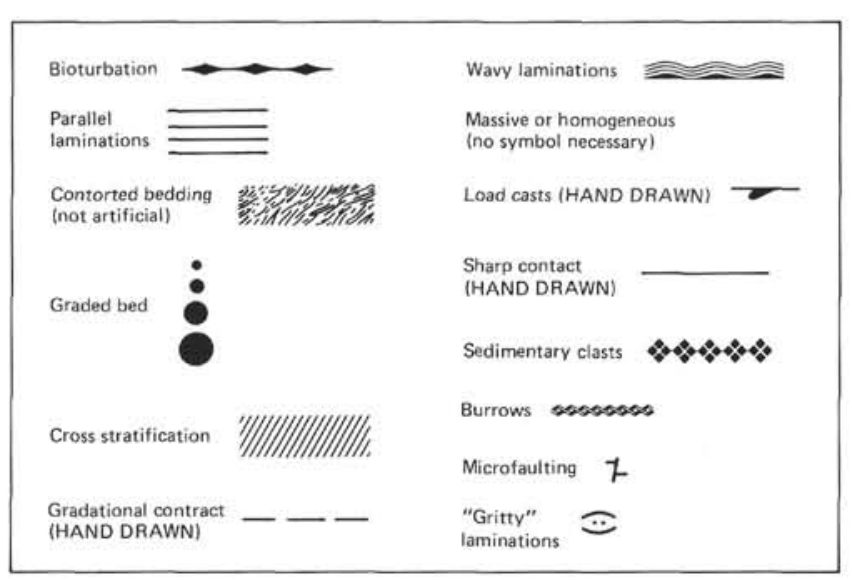

Figure 12. Sedimentary structure symbols.

make up the remainder of this volume. Insofar as possible the lithologic data for the main lithology are presented in the following order:

Sediment or rock name

Color name and GSA (or Munsell) number

General Description of the core including disturbance, sedimentary structures and other special features

Composition from smear slides and/or thin sections

Carbon-carbonate determinations

Grain-size determinations

$\mathrm{X}$-ray mineralogy

Many cores contain important minor lithologies as well as the major lithology and descriptive information is included for these wherever possible.

An exemplary core description form showing all symbols and explanatory notes is included herewith (Figure 13) as an aid to understanding and utilizing the core data presented in the remainder of this volume.

\section{Biostratigraphy}

Planktonic foraminiferal zonation presented herein is based on the number scheme developed by Blow (1969) and Berggren (1972a, b) for the Tertiary and Quaternary sequences. The Mesozoic sequences are zoned according to the scheme of Sigal (in press) (Figure 14). The calcareous nannofossil zonation follows Martini (1971a, b) for the Tertiary and Quaternary. The zonation given by Thierstein $(1971,1973)$ was used for the Lower Cretaceous. Age determinations for the Upper Cretaceous are based on the zonation used by Roth (1973) which combines zones established by Martini (1961), Cepek and Hay (1969), Bukry and Bramlette (1970), and Manivit (1971).

Wherever possible, zone boundaries are based upon the nominate species of the original zone definition. However, in those cases where the nominate species were absent, for whatever reason, other species have been utilized, ranges of which are reasonably well known from areas where they occur together with the nominate species. In several instances, in the absence of any diagnostic species, zonal boundaries could not be recognized at all.

Absolute age assignments were made in reference to the Neogene scale of Ryan et al. (1974) and to the Paleogene scale of Hardenbol and Berggren (in preparation). The time 


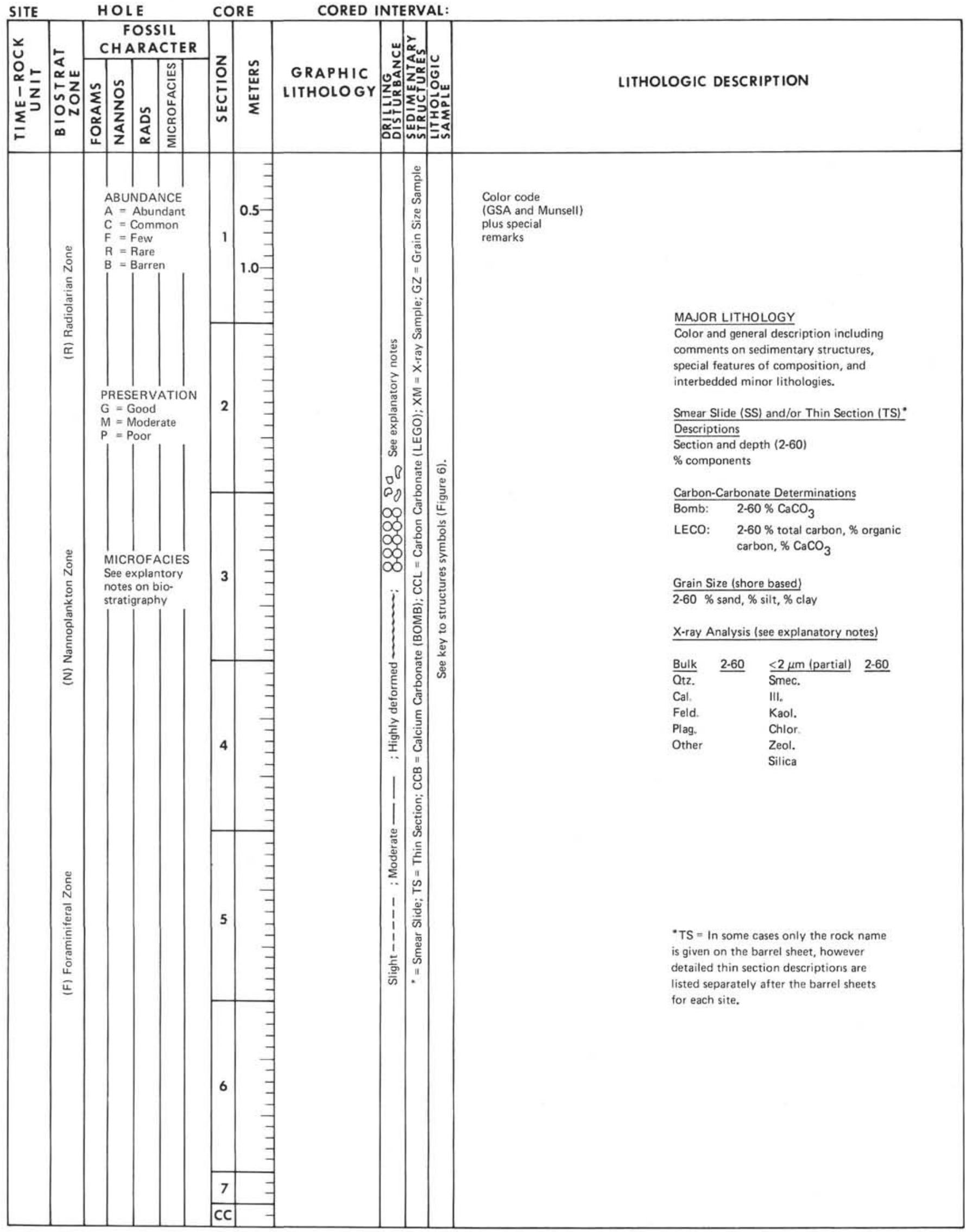

Figure 13. Sample core description. 


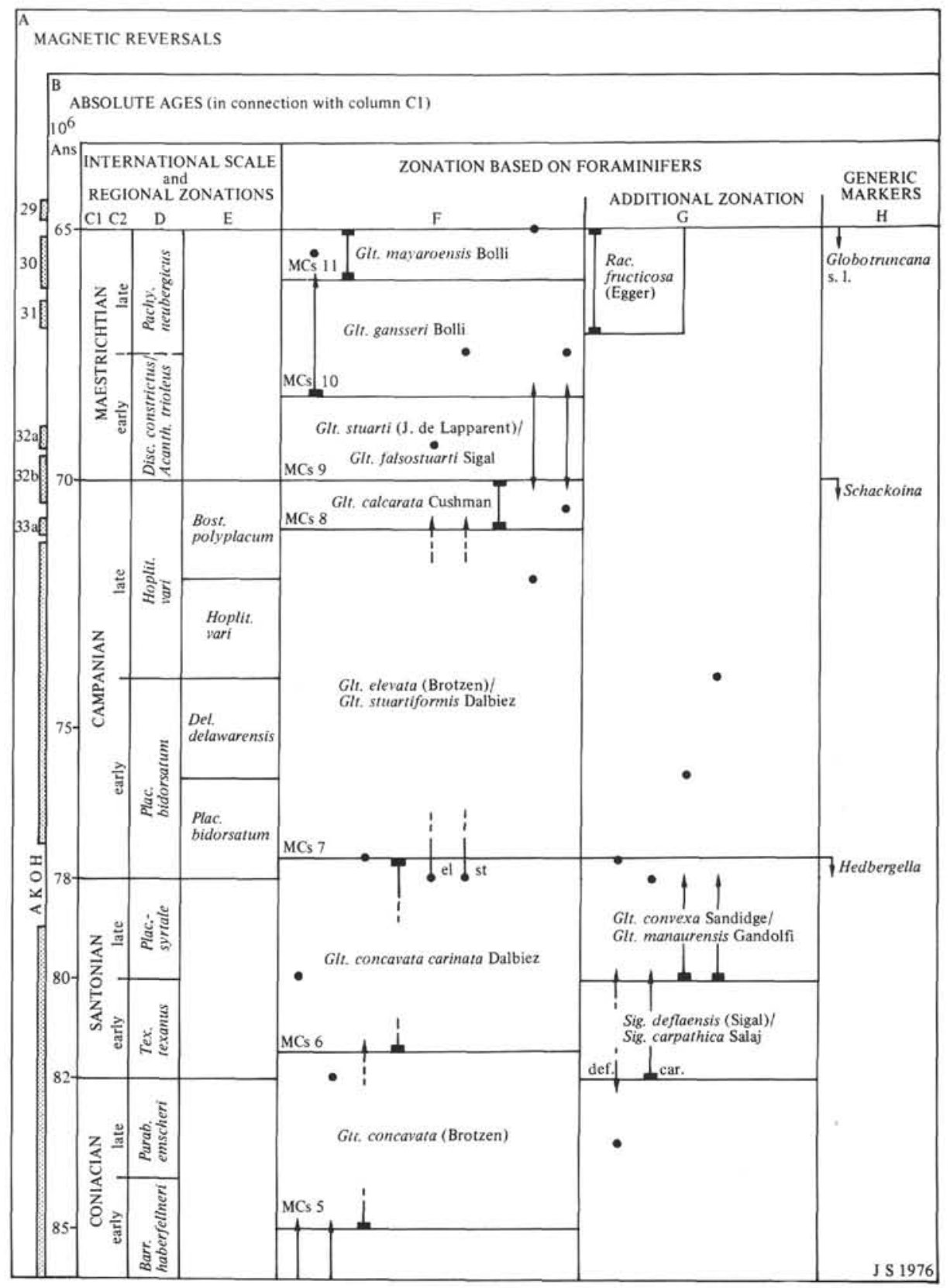

Figure 14. Cretaceous foraminiferal zonation of Sigal (1977).

scale given by van Hinte (1976) was used for the Cretaceous.

Some sediments were too hard to wash for microfossils. In these cases, thin sections were made and stratigraphic ages were assigned either by: (1) recognition of certain marker species, or (2) comparison of the entire microfacies to that in samples from land sections. Ages so determined are indicated by the symbol $\mathrm{M}$ (for microfacies) on the barrel sheets, and the numbers listed in the microfacies column refer to quantity of thin sections studied.

\section{REFERENCES}

Berger, W.H. and Winterer, E.L., 1974. Plate stratigraphy and the fluctuating carbonate line, Spec. Publ. Internat. Assoc. Sediment., no. 1, p. 11-48.
Berggren, W.A., 1972a. A Cenozoic time-scale - some implications for regional geology and paleobiogeography, Lethaia, v. 5, p. 195-215.

1972b. Cenozoic biostratigraphy and paleobiogeography of the North Atlantic. In Laughlin, A.S., Berggren, W.A., et al., Initial Reports of the Deep Sea Drilling Project, v. 12: Washington (U.S. Government Printing Office), p. 965-1001.

Blow, W.H., 1969. Late middle Eocene to Recent planktonic foraminiferal biostratigraphy. In Brönnimann, P. and Renz, H.H. (Eds.), Internat. Conf. Plankt. Microfossils, 1st, Proc.: Leiden (E.J. Brill), p. 199-241.

Boyce, R.E., 1973. Physical properties - methods. In Edgar, N.T., Saunders, J.B., et al., Initial Reports of the Deep Sea Drilling Project, v. 15: Washington (U.S. Government Printing Office), p. 1115-1127.

, 1976. Definitions and laboratory techniques of compressional sound velocity parameters and wet water 


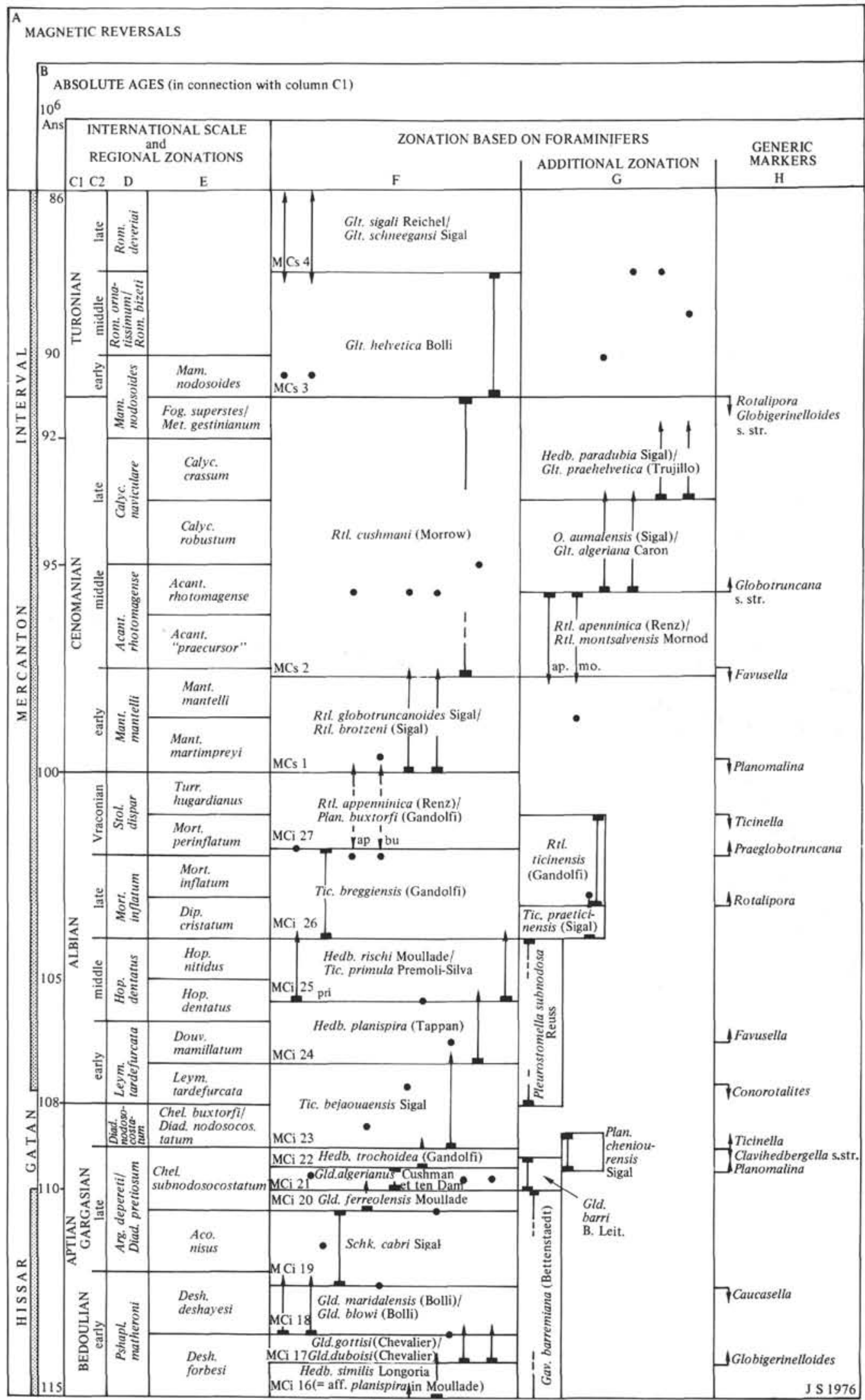




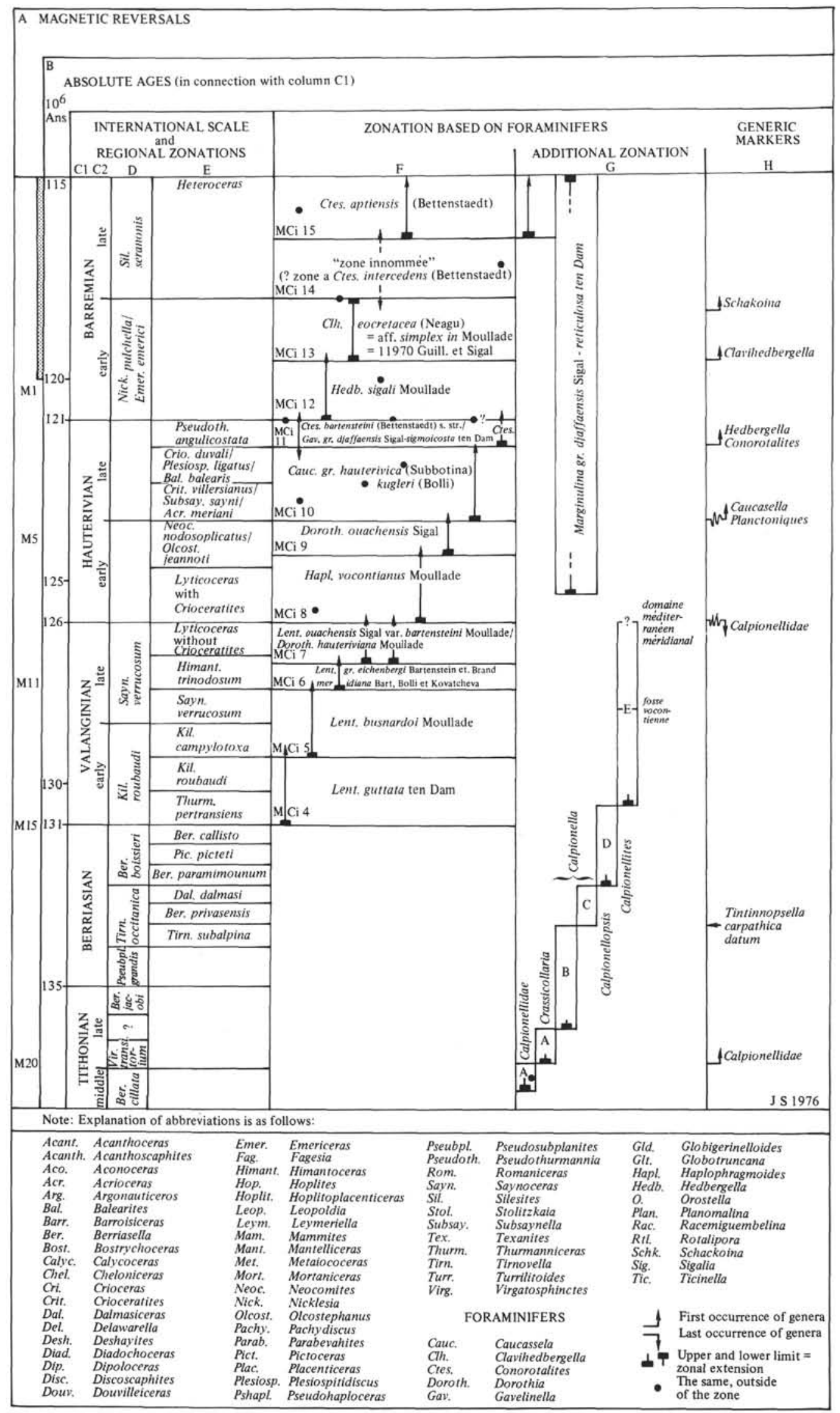

Figure 14. Continued. 
content, wet-bulk density, and porosity parameters by gravimetric and gamma ray attenuation techniques. In Larson, R.L., Moberly, R., et al., Initial Reports of the Deep Sea Drilling Project, v. 32: Washington (U.S. Government Printing Office), p. 931-958.

Bukry, D., 1973. Coccolith and silicoflagellate stratigraphy, Deep Sea Drilling Project Leg 18, Eastern north Pacific. In Kulm, L.D., von Huene, R., et al., Initial Reports of the Deep Sea Drilling Project, v. 18: Washington (U.S. Government Printing Office), p. 817-831.

Bukry, D. and Bramlette, M.N., 1970. Coccolith age determinations Leg 3, Deep Sea Drilling Project. In Maxwell, A.E., von Herzen, R., et al., Initial Reports of the Deep Sea Drilling Project, v. 3: Washington (U.S. Government Printing Office), p. 589-611.

Cepek, P. and Hay, W.W., 1969. Calcareous nannoplankton and biostratigraphic subdivision of the Upper Cretaceous, Gulf Coast Assoc. Geol. Soc. Trans., v. 19, p. 323-336.

Cuvillier, J., 1961. Stratigraphic correlations by microfacies in western Aquitaine, Internat. Sedimentary Petrographical Series: Netherlands (E.J. Brill).

Dunham, R.J., 1962. Classification of carbonate rocks according to depositional texture. In Ham, W.E., (Ed.), Classification of Carbonate Rocks, Am. Assoc. Petrol. Geol. Mem. 1, p. 108121.

Hardenbol, J. and Berggren, W.W., in preparation. A new Paleogene numerical time scale.

Manivit, H., 1971. Nannofossiles calcaires du Crétacé français (Aptien-Maestrichtien). Essai de biozonation appuyée sur les stratotypes; Thesis Facul. Sci. Orsay.

Martini, E., 1961. Nannoplankton aus dem Tertiär und der obersten Kreide von SW-Franreich: Senckenb. Leth., v. 42, p. 1.

Martini, E., 1971a. Neogene silicoflagellates from the equatorial Pacific. In Winterer, E.L., Riedel, W.R., et al., Initial Reports of the Deep Sea Drilling Project, v. 7, Part 2: Washington (U.S. Government Printing Office), p. 1695-1708. , 1971b. Standard Tertiary and Quaternary calcareous nannoplankton zonation, Second Plankt. Conf. Proc., Roma 1970 , v. 2 , p. $739-785$.

Matthews, D.J., 1939. Tables of the velocity of sound in pure water and in seawater: Hydrographic Department, Admiralty, London.
Moberly, R. Jr., and Heath, G. R., 1971. Carbonate sedimentary rocks from the western Pacific: Leg 7, Deep Sea Drilling Project. In Winterer, E.L., Riedel, W.R., et al., Initial Reports of the Deep Sea Drilling Project, v. 7, Part 2: Washington (U.S. Government Printing Office), p. 977-985.

Montadert, L., Roberts, D.G., et al., 1976. Glomar Challenger sails on Leg 48, Geotimes, v. 21, p. 19-23. , 1977. Rifting and subsidence on passive continental margins in the Northeast Atlantic, Nature, v. 268, p. 305-309.

Roth, P.H., 1973. Calcareous nannofossils - Leg 17, Deep Sea Drilling Project. In Winterer, E.L., Ewing, J.L., et al., Initial Reports of the Deep Sea Drilling Project, v. 17: Washington (U.S. Government Printing Office), p. 695-795.

Ryan, W.B.F., et al., 1974. A paleomagnetic assignment of Neogene stage boundaries and the development of isochronus datum planes between the Mediterranean, Pacific and Indian oceans in order to investigate the response of the World Ocean to the Mediterranean "Salinity Crisis,"' Riv. Ital. Paleontol., v. 80 , p. $631-688$.

Schlumberger Limited, 1972. Schlumberger Log Interpretation, Volume 1: Principles.

Sigal, J., in press. Essai de zonation du Crétacé Méditerranéen à l'aide des foraminifères planctoniques, Géol. Méditerranéene.

Thierstein, H.R., 1971. Tentative Lower Cretaceous calcareous nannoplankton zonation, Eclog. Geol. Helv., v. 64, p. 459-588.

, 1973. Lower Cretaceous calcareous nannoplankton biostratigraphy, Abh. Geol. Bundesanst., Wien, v. 29, p. 3-52.

van Hinte, J.E., 1976. A Cretaceous time scale, Am. Assoc. Petrol. Geol. Bull., v. 60 (4), p. 498-516.

Wentworth, C.K., 1922. A scale of grade and class terms of clastic sediments, Jour. Geol., v. 30, p. 377.

Wentworth, C.K. and Williams, H., 1932. The classification and terminology of the pyroclastic rocks, Bull. Nat. Research Council, no. 89, p. 19-53.

Wyllie, M.R.J., Gregary, H.R., and Gardner, L.W., 1956. Elastic waves in heterogeneous and porous media, Geophysics, v. 21 , p. 41 .

Wyllie, M.R.J., Gregory, A.R., and Gardner, G.H.F., 1958. An experimental investigation of factors affecting elastic wave velocities in porous media, Geophysics, v. 23, p. 459. 